\title{
Klantcontact : rekrutering, competenties en perspectieven van medewerkers in callcenters
}

Citation for published version (APA):

de Grip, A., \& Sieben, I. J. P. (2001). Klantcontact : rekrutering, competenties en perspectieven van medewerkers in callcenters. Researchcentrum voor Onderwijs en Arbeidsmarkt, Faculteit der Economische Wetenschappen. ROA Reports No. 9 https://doi.org/10.26481/umarep.2001009

Document status and date:

Published: 01/01/2001

DOI:

10.26481/umarep.2001009

Document Version:

Publisher's PDF, also known as Version of record

\section{Please check the document version of this publication:}

- A submitted manuscript is the version of the article upon submission and before peer-review. There can be important differences between the submitted version and the official published version of record.

People interested in the research are advised to contact the author for the final version of the publication, or visit the DOI to the publisher's website.

- The final author version and the galley proof are versions of the publication after peer review.

- The final published version features the final layout of the paper including the volume, issue and page numbers.

Link to publication

\footnotetext{
General rights rights.

- You may freely distribute the URL identifying the publication in the public portal. please follow below link for the End User Agreement:

www.umlib.nl/taverne-license

Take down policy

If you believe that this document breaches copyright please contact us at:

repository@maastrichtuniversity.nl

providing details and we will investigate your claim.
}

Copyright and moral rights for the publications made accessible in the public portal are retained by the authors and/or other copyright owners and it is a condition of accessing publications that users recognise and abide by the legal requirements associated with these

- Users may download and print one copy of any publication from the public portal for the purpose of private study or research.

- You may not further distribute the material or use it for any profit-making activity or commercial gain

If the publication is distributed under the terms of Article $25 \mathrm{fa}$ of the Dutch Copyright Act, indicated by the "Taverne" license above, 


\section{Klantcontact \\ Rekrutering, competenties en perspectieven van medewerkers in callcenters}

ROA-R-2001/9

Andries de Grip

Inge Sieben

Researchcentrum voor Onderwijs en Arbeidsmarkt

Faculteit der Economische Wetenschappen en Bedrijfskunde Universiteit Maastricht

Maastricht, december 2001 


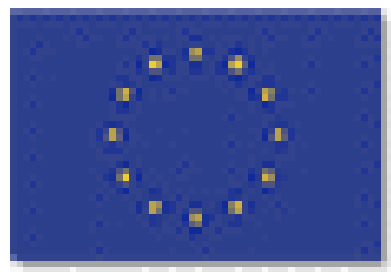

De partners in dit project
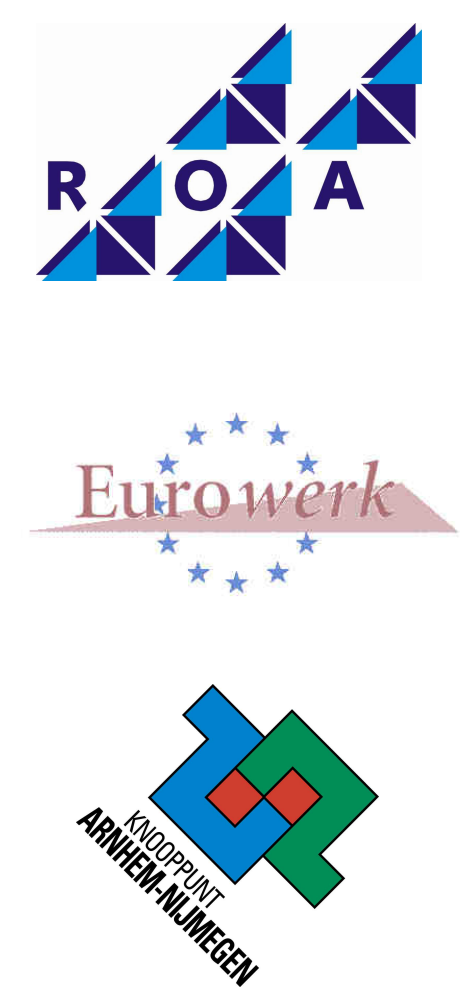

Dit project is mede mogelijk gemaakt dankzij het Europees Fonds voor Regionale Ontwikkeling
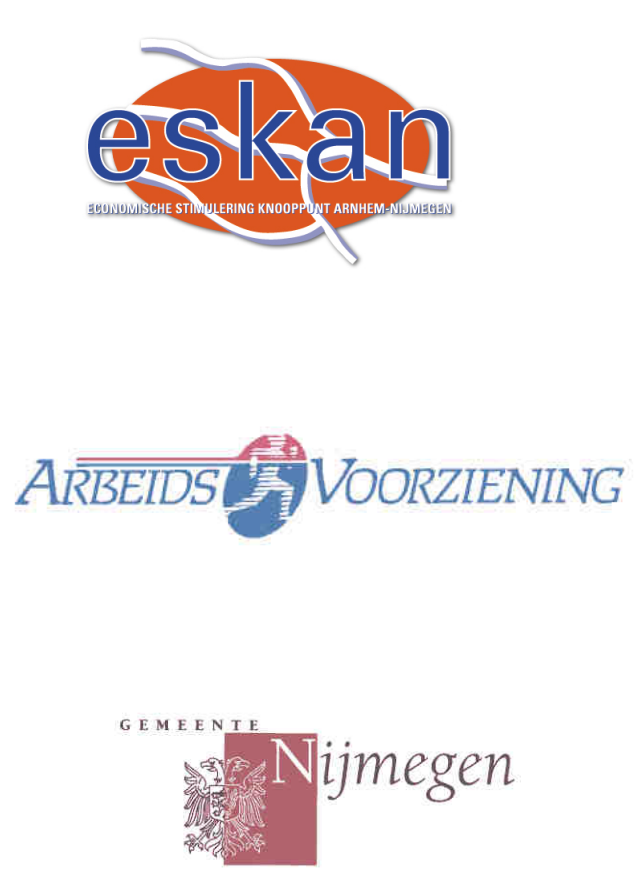

Arnhem

ISBN 90-5321-323-6

Sec01.404.doc 


\section{Inhoud}

Bladzijde

Voorwoord

Managementsamenvatting iii

1 Inleiding 1

1.1 Inleiding 1

1.2 Opzet van dit rapport 3

2 Callcenters en hun medewerkers 5

2.1 Inleiding 5

2.2 De callcenters in dit rapport 5

2.3 De achtergronden van medewerkers $\quad 7$

2.4 Aspecten van het werk als medewerker klantcontact 10

3 Opleiding en competenties van medewerkers $\quad 15$

$\begin{array}{ll}3.1 \text { Inleiding } & 15\end{array}$

$\begin{array}{ll}3.2 & \text { Opleidingsachtergrond van medewerkers } \\ 3.3 & 15\end{array}$

$\begin{array}{ll}3.3 \text { Competenties } & 18\end{array}$

$\begin{array}{lll}3.4 & \text { Skill gaps } & 19\end{array}$

4 Inspelen op skill gaps $\quad 25$

4.1 Inleiding 25

4.2 Deelname aan cursussen $\quad 25$

4.3 Redenen om cursussen te volgen $\quad 27$

$\begin{array}{lll}4.4 & \text { Tevredenheid met cursussen } & 29\end{array}$

$\begin{array}{lll}4.5 & \text { Wens naar toekomstige cursussen } & 29\end{array}$

5 Competenties, werkervaring en arbeidsmarktpositie 31

$\begin{array}{ll}5.1 \text { Inleiding } & 31\end{array}$

$\begin{array}{lll}5.2 & \text { Loopbaanperspectieven } & 31\end{array}$

$\begin{array}{lll}5.3 & \text { Redenen om elders te gaan werken } & 34\end{array}$

$\begin{array}{lll}5.4 & \text { Arbeidsmarktperspectieven } & 36\end{array}$

$\begin{array}{ll}\text { Literatuur } & 41\end{array}$

Bijlage: Vragenlijsten $\quad 43$ 



\section{Voorwoord}

In het kader van het Actieprogramma Callcenters heeft het Telebusiness Innovatieproject (TIP) een monitorstudie opgezet naar de arbeidsmarktsituatie voor callcenters in de regio Arnhem/Nijmegen. De uitvoering van het TIP ligt bij de stichting Economische Stimulering Knooppunt Arnhem-Nijmegen (ESKAN). Samen met het Researchcentrum voor Onderwijs en Arbeidsmarkt (ROA) heeft ESKAN in september en oktober 2001 een enquêteonderzoek uitgevoerd onder de medewerkers klantcontact bij acht callcenters in de regio Arnhem/Nijmegen. Het voorliggende rapport beschrijft de belangrijkste bevindingen van dit werknemersonderzoek.

De onderzoekers danken in de eerste plaats drs. Remco Hoogendijk en drs. Christian Heerings van ESKAN voor de organisatie van het veldwerk. Zij willen ook hun dank uitspreken naar managers en medewerkers klantcontact van de callcenters in de regio Arnhem/Nijmegen die aan het onderzoek hebben deelgenomen, namelijk Dutchtone, ING Customer Contact Center, ING Postbank Particulieren, ING Postbank Zakelijk en Marketel te Arnhem, Polis Direkt en Van Wissen Telemarketing te Nijmegen, en NEC Packard Bell te Wijchen. 



\section{Managementsamenvatting}

In dit rapport is ingegaan op een aantal vragen met betrekking tot de arbeidsmarktpositie van de medewerkers klantcontact van callcenters. Dit thema is van belang omdat het voor callcenters vaak een probleem is om de personeelsvraag en het aanbod van arbeid op elkaar af te stemmen. Door de huidige krapte op de arbeidsmarkt ondervinden callcenters moeilijkheden bij de werving van nieuw personeel. Daarnaast is het personeelsverloop onder medewerkers klantcontact groot. Naast deze problemen van kwantitatieve aard, is er mogelijk ook sprake van kwalitatieve knelpunten in de aansluiting tussen opleiding en werk in de callcenter sector. Om de functie van medewerker klantcontact adequaat te kunnen uitoefenen, zijn bepaalde kennis en vaardigheden nodig. Het is dan ook van belang dat de competenties waarover werknemers beschikken, aansluiten op hun functie. Wanneer er sprake is van competentietekorten oftewel skill gaps, dan zullen deze aangevuld moeten worden, bijvoorbeeld door te investeren in cursussen en trainingen van het personeel.

Om deze kwantitatieve en kwalitatieve knelpunten in de callcenter sector te kunnen verminderen, is goede informatie over de arbeidsmarktpositie van de medewerkers klantcontact nodig. Hiervoor zijn ruim 500 medewerkers klantcontact en hun managers in acht callcenters in de regio Arnhem/Nijmegen ondervraagd. Deze acht callcenters verschillen op een aantal aspecten van elkaar. Zo zijn er verschillen in het soort contact center (in-house of outsourcing), het soort gesprekken (inbound en/of outbound), de activiteiten die men uitoefent (service, verkoop, helpdesk, klachtenafhandeling en/of databaseverrijking en controle ${ }^{1}$ ), de omvang (van 80 tot 600 werknemers) en het beloningssysteem (alleen vast honorarium of ook prestatietoeslag). Het onderzoek richtte zich op vier hoofdvragen:

- Op welke arbeidsmarktsegmenten rekruteren callcenters in de regio Arnhem/Nijmegen hun medewerkers klantcontact?

Het blijkt dat de acht onderzochte callcenters in de regio Arnhem/Nijmegen hun medewerkers klantcontact over het algemeen dichtbij huis rekruteren: de gemiddelde enkele reistijd bedraagt 31 minuten. De grootste doelgroep die interessant is voor callcenters zijn vrouwen jonger dan 25 jaar. Maar ook mannen onder de 40 jaar worden vaak door callcenters in dienst genomen. De helft van de medewerkers klantcontact heeft een partner en een kwart thuiswonende kinderen, die vaak nog zeer jong zijn. Naast hun baan bij het callcenter genieten zij voornamelijk van hun vrije tijd (met name diegenen die 32 uur of meer per week werken), of volgen ze een studie of verrichten zorgtaken (met name diegenen die minder dan 32 uur per week werken).

De meeste callcenters hebben medewerkers klantcontact in dienst die daar nog maar relatief kort werken (ongeveer 2 jaar). Medewerkers met een vast contract

1. Geen van de acht onderzochte callcenters in de regio Arnhem/Nijmegen verrichtte marktonderzoek. 
werken beduidend langer bij een callcenter. De gemiddelde werkweek omvat 30 uur en over het algemeen wordt dit ook als het ideale aantal werkuren beschouwd. Wel wil ongeveer een kwart van de medewerkers graag minder gaan werken, terwijl met name oproepkrachten graag meer werkuren zouden willen. De meeste medewerkers werken tijdens kantooruren; de helft werkt ook wel eens in het weekend of op feestdagen. De werkzaamheden van medewerkers klantcontact bestaan voor het merendeel uit het voeren van inbound gesprekken, dat wil zeggen dat een klant naar het callcenter belt en daar te woord gestaan wordt. Het modale bruto uurloon van medewerkers klantcontact bedraagt iets meer dan fl. 22,-. Oproepkrachten verdienen een stuk minder.

- Is er sprake van bepaalde 'skill gaps' bij de medewerkers klantcontact die werkzaam zijn bij callcenters?

Om de functie van medewerker klantcontact adequaat te kunnen uitoefenen, dienen ze over bepaalde competenties te beschikken. Over het algemeen zijn bij de onderzochte callcenters redelijk hoogopgeleide medewerkers werkzaam. De feitelijk gevolgde opleiding lijkt geen doorslaggevende rol te spelen bij de werving van personeel, alhoewel er een voorkeur lijkt te bestaan voor medewerkers klantcontact die een MBO opleiding in de richting 'economie en administratie' afgerond hebben. Verder blijkt taalbeheersing van belang te zijn om aan de slag te kunnen bij een callcenter waar internationale gesprekken plaatsvinden. De medewerkers klantcontact in deze bedrijven zijn beter in Engels dan de medewerkers in de overige vier callcenters. Over het algemeen geldt dat medewerkers het Engels goed beheersen, maar wat meer moeite met Duits en Frans hebben.

Naar eigen zeggen beschikken medewerkers klantcontact in voldoende mate over competenties die het belangrijkst zijn voor het vervullen van hun functie, dat wil zeggen 'klantgerichtheid', 'basisgesprekstechnieken', 'probleemoplossend vermogen' en 'computervaardigheden'. Alleen op 'productkennis', die door de managers van de callcenters juist erg belangrijk gevonden wordt, scoren zij minder goed. Opmerkelijk is dat er geen grote competentieverschillen tussen lager en hoger opgeleiden gevonden worden. Toch is er bij een deel van de medewerkers klantcontact sprake van aanzienlijke competentietekorten. Deze skill gaps doen zich met name voor op het terrein van 'telefonische verkooptechniek', 'bedrijfskennis', 'productkennis', 'talenkennis' en 'onderhandelingstechnieken'. Medewerkers klantcontact die in een in-house contact center werken schieten op het punt van hun 'telefonische verkooptechniek' vaak te kort. Daarentegen hebben medewerkers, die in een outsourcing contact center werkzaam zijn, weer vaker competentietekorten in hun bedrijfs- en productkennis. Laag opgeleiden en mensen die in deeltijd werken hebben vaker met skill gaps op het gebied van 'talenkennis' en 'onderhandelingstechnieken' (twee meer algemene competenties) te maken.

- Op welke wijze wordt er in callcenters ingespeeld op de aanwezige skill gaps bij medewerkers klantcontact? 
Skill gaps kunnen doorgaans worden weggewerkt door te investeren in aanvullende scholing. Alle acht onderzochte callcenters bieden hun medewerkers klantcontact dan ook cursussen en trainingen aan, die met name gericht zijn op de specifiek op het werken in een callcenter vereiste kennis en vaardigheden. In het afgelopen jaar heeft 63 procent van de medewerkers klantcontact één of meerdere van deze cursussen gevolgd. Als reden voor het volgen van deze cursussen gaf men vaak aan dat deze verplicht was. Dit houdt in dat de werkgevers het initiatief nemen tot het verminderen van skill gaps. Bedrijfskenmerken blijken ook van doorslaggevende betekenis te zijn wanneer het gaat om cursusparticipatie. Zo nemen medewerkers klantcontact die werkzaam zijn in een in-house contact center of in een klein callcenter eerder aan cursussen deel.

Over het algemeen kan gesteld worden dat medewerkers die een cursus gevolgd hebben, minder grote skill gaps hebben, met name op de terreinen 'productkennis', 'bedrijfskennis', telefonische verkooptechniek' en 'onderhandelingstechnieken'. Daarnaast speelt ook het leren op de werkplek een rol in het terugdringen van skill gaps. Werknemers met veel werkervaring hebben minder grote skill gaps in de competenties 'probleemoplossing', 'productkennis', 'computervaardigheden' en 'telefonische verkooptechniek'.

Overigens is ongeveer driekwart van de medewerkers klantcontact tevreden over de aangeboden scholingsfaciliteiten en de begeleiding op de werkplek. De wens naar toekomstige cursussen is groot. Maar liefst 61 procent van de medewerkers klantcontact denkt in het komende jaar een cursus te gaan volgen. In het algemeen geven medewerkers met een skill gap vaker aan in de toekomst een cursus of training op dat gebied te willen volgen. Dit wijst erop dat men zelf ook goed aanvoelt dat men er op bepaalde punten wat aan moet doen om adequaat te kunnen functioneren.

- Welke arbeidsmarktperspectieven denken medewerkers klantcontact binnen en buiten de callcentersector te hebben?

40 procent van de medewerkers klantcontact geeft aan binnen 2 jaar een andere baan te overwegen. Mannen, jongeren en medewerkers met een tijdelijk contract willen wat vaker in een andere baan aan de slag, vooral buiten de callcentersector. Competente medewerkers klantcontact overwegen wat vaker bij een ander callcenter te gaan werken dan minder competente medewerkers. Medewerkers die slecht scoren op de competenties 'motivatie', 'omgaan met kwaadheid en agressie' en 'klantgerichtheid' overwegen vaker een andere baan buiten de sector dan medewerkers die wel over deze competenties beschikken. Het zijn dus juist de medewerkers met weinig competenties die vaker een andere baan overwegen dan degenen met veel competenties. Dit betekent dat callcenters met een gerust hart kunnen investeren in cursussen en trainingen van hun medewerkers. Immers, medewerkers klantcontact vertrekken minder vaak naar een ander callcenter wanneer ze hun competenties hebben vergroot. Het investeren in de competenties van medewerkers klantcontact lijkt daarmee een uitstekend middel om hen te 'binden en boeien'. 
Over het algemeen geven medewerkers klantcontact aan dat de betere loopbaanperspectieven en het hogere salaris elders redenen zijn om daar te willen gaan werken. Bij het overwegen van een baan buiten de sector speelt ook mee dat het werk als medewerker klantcontact niet als bevredigend ervaren wordt. Verder bestaat er een duidelijke samenhang tussen het elders willen gaan werken en de ontevredenheid met aspecten van het werk. Over het algemeen zijn medewerkers klantcontact echter zeer tevreden over hun werk, al is er één callcenter dat hier beduidend slechter op scoort.

Ongeveer driekwart van de medewerkers klantcontact, en met name jongeren, denkt dat het niet moeilijk is om een even aantrekkelijke baan bij een ander callcenter of buiten de sector te vinden. lemands competenties lijken overigens weinig invloed op deze mening te hebben, dit in tegenstelling tot iemands werkervaring. Medewerkers klantcontact met veel werkervaring denken wel dat ze gewilder zijn op de arbeidsmarkt voor callcenters, maar vinden het tevens moeilijker om een even aantrekkelijke baan buiten de callcentersector te vinden dan medewerkers met weinig werkervaring.

\section{Conclusies}

Het in dit rapport gepresenteerde onderzoek heeft een aantal belangrijke implicaties voor het Human Resource Management (HRM) beleid van callcenters. Een belangrijke conclusie is dat het investeren in cursussen en trainingen voor medewerkers klantcontact hout blijkt te snijden, en wel om twee redenen. In de eerste plaats kunnen callcenters door het opleiden van hun medewerkers hiaten in kennis en vaardigheden aanvullen. Het blijkt dat bestaande skill gaps bij medewerkers klantcontact hierdoor verdwijnen, waardoor zij hun functie beter kunnen uitoefenen. In de tweede plaats blijkt dat competente medewerkers minder snel omzien naar een andere baan binnen of buiten de callcentersector. Het aanbieden van cursussen en trainingen aan medewerkers klantcontact is daardoor een belangrijk middel om werknemers te binden en te boeien.

Een tweede belangrijke conclusie die wij uit het onderzoek zouden willen trekken is dat het investeren in cursussen en trainingen de callcenters meer perspectief biedt dan het opzetten van een specifieke opleiding voor medewerkers klantcontact in het reguliere onderwijs. Uit het onderzoek blijkt dat de opleidingsachtergrond van medewerkers klantcontact zeer divers is. Juist deze opleidingsbreedte biedt callcenters een grotere actieradius op de arbeidsmarkt. Overigens geldt hetzelfde ook voor het arbeidsaanbod. lemand die een specifiek op de callcentersector gerichte opleiding gevolgd heeft, heeft minder uitwijkmogelijkheden op de arbeidsmarkt. Uit het rapport van de Stuurgroep Evaluatie Wet Educatie Beroepsonderwijs (2001) komt naar voren dat er teveel sectorspecifieke MBOopleidingen bestaan. Een aparte afstudeerrichting 'klantcontact' heeft vanuit het perspectief van de leerlingen ook het nadeel dat men zich veel sterker specialiseert dan wanneer men een breder georiënteerde afstudeerrichting binnen de sector economie kiest. Veel leerlingen zullen daarom waarschijnlijk niet voor een specifieke richting kiezen, maar een bredere economisch-commerciële MBO-opleiding 
prefereren. Wel zou het goed zijn om binnen deze bredere opleidingen meer aandacht te besteden aan de kennis en vaardigheden die gevraagd worden voor het werk in callcenters. De keuze van ROC's in de regio Arnhem/Nijmegen om aparte modules klantcontact binnen bestaande $\mathrm{MBO}$-opleidingen aan te bieden lijkt daarmee een slimme zet.

Wel moet opgemerkt worden dat van medewerkers klantcontact waarschijnlijk steeds vaker verwacht zal worden dat zij over minimaal een MBO-opleiding beschikken. Niet alleen vanwege de toenemende complexiteit van hun werkzaamheden, maar ook het feit dat het merendeel van de klanten een opleiding op MBO-niveau of hoger gevolgd heeft, is hier debet aan. Aangezien de regio Arnhem/Nijmegen over een aanzienlijk hoog opgeleid arbeidspotentieel beschikt, biedt dit perspectieven voor de toekomstige werving van medewerkers klantcontact.

Ten slotte kunnen we nog stellen dat callcenters een waardevolle maatschappelijke functie vervullen. Zij bieden goede perspectieven voor werknemers die werk willen combineren met zorgtaken of het volgen van een opleiding. Voor de callcenters zelf betekent dit overigens ook dat men op deze segmenten van de arbeidsmarkt een sterke positie inneemt. Dit blijkt onder andere uit het feit dat een kwart van de medewerkers naast hun werk nog een opleiding volgt en uit het hoge percentage vrouwen met relatief jonge kinderen dat werkzaam is bij callcenters. Goede faciliteiten voor kinderopvang blijken wel belangrijk om medewerkers vast te houden. 



\section{Inleiding}

\subsection{Inleiding}

In dit rapport wordt ingegaan op een aantal vragen met betrekking tot de arbeidsmarktpositie van de medewerkers klantcontact van callcenters. Dit thema is van belang omdat het voor callcenters vaak een probleem is om de vraag naar en het aanbod van arbeid op elkaar af te stemmen. Momenteel werken er zo'n 160.000 mensen in de callcentersector (von Pickartz \& van Stigt, 2002). Door de huidige krapte op de arbeidsmarkt ondervinden callcenters moeilijkheden bij de werving van nieuw personeel. Daarnaast is het personeelsverloop onder medewerkers klantcontact groot. Callcenters hebben vaak moeite om het zittende personeel voor hun bedrijf te behouden. Dit plaatst de problematiek van 'binden en boeien' prominent op de agenda van het personeelsbeleid van callcenters.

Naast deze problemen van kwantitatieve aard, is er mogelijk ook sprake van kwalitatieve knelpunten in de aansluiting tussen opleiding en werk in de callcenter sector. Om de functie van medewerker klantcontact adequaat te kunnen uitoefenen, zijn bepaalde kennis en vaardigheden nodig. Het is dan ook van belang dat de competenties waarover werknemers beschikken, aansluiten op hun functie. Wanneer er sprake is van competentietekorten oftewel skill gaps, dan zullen deze aangevuld moeten worden, bijvoorbeeld door te investeren in cursussen en trainingen van het personeel.

Het is mogelijk dat callcenters zich in dit opzicht in een vicieuze cirkel bevinden. Competente medewerkers klantcontact zijn immers op de krappe arbeidsmarkt aantrekkelijk voor andere werkgevers. Dit verhoogt hun vertrekkans: zij zullen eerder het callcenter verlaten om elders (zowel binnen als buiten de sector) aan de slag te gaan. Wanneer dit het geval is, dan blijven de minder competente werknemers bij het callcenter werken, terwijl het bedrijf niet profiteert van de investeringen die het heeft gedaan in de competenties van het personeel. Ook de nieuwkomers, die geworven worden om de opengevallen posities op te vullen, beschikken vaak niet over de benodigde competenties. Deze tekorten aan kennis en vaardigheden moeten weer weggewerkt worden door hen cursussen en trainingen te laten volgen, waarna ook deze medewerkers weer een hogere vertrekkans hebben omdat zij door hun aangevulde competenties aantrekkelijk worden voor andere werkgevers.

Om deze mogelijke kwantitatieve en kwalitatieve knelpunten in de callcenter sector te kunnen verminderen, is goede informatie over de arbeidsmarktpositie van de medewerkers klantcontact nodig. Allereerst zal er een goede definitie gevonden moeten worden van de arbeidsmarktsegmenten waarop callcenters hun personeel werven, bijvoorbeeld in termen van woonregio en achtergronden van hun medewerkers. Ook aspecten, die met het werk van medewerkers klantcontact te maken hebben, zijn hierbij van belang. Door de kenmerken van medewerkers klantcontact te beschrijven wordt een antwoord verkregen op de eerste hoofdvraag in dit onderzoek. 
- Op welke arbeidsmarktsegmenten rekruteren callcenters in de regio Arnhem/Nijmegen hun medewerkers klantcontact?

In de tweede plaats is het van belang inzicht te krijgen in de competenties van medewerkers klantcontact. Om hun functie adequaat te kunnen vervullen spelen de kennis en vaardigheden waarover mensen beschikken een grote rol. Door de opleidingsachtergronden en competenties van medewerkers klantcontact in kaart te brengen, kan nagegaan worden of deze voldoende aansluiten op hun functie. Dit leidt tot een antwoord op de tweede hoofdvraag in dit onderzoek.

- Is er sprake van bepaalde 'skill gaps' bij de medewerkers klantcontact die werkzaam zijn bij callcenters?

Skill gaps kunnen opgelost worden door het investeren in aanvullende scholing. Daarom zal er in dit rapport aandacht besteed worden aan de participatie van medewerkers klantcontact in cursussen en trainingen. Daarnaast kunnen bepaalde competenties verworven worden door het opbouwen van voldoende werkervaring. Beide aspecten staan centraal in de derde hoofdvraag van dit onderzoek.

- Op welke wijze wordt er in callcenters ingespeeld op de aanwezige skill gaps bij medewerkers klantcontact?

In aansluiting hierop zal ingegaan worden op de concurrentiepositie van callcenters op de arbeidsmarkt, zoals die naar voren komt uit de door werkenden gepercipieerde mogelijkheden om binnen en buiten de callcenter sector werk te vinden. Ook wordt onderzocht in hoeverre de competenties en werkervaring waarover medewerkers klantcontact beschikken van invloed zijn op hun arbeidsmarktpositie binnen en buiten de callcentersector. Dit leidt tot de vierde hoofdvraag van dit onderzoek.

- Welke arbeidsmarktperspectieven denken medewerkers klantcontact binnen en buiten de callcentersector te hebben?

Om tot een antwoord op deze vier hoofdvragen te komen, zijn medewerkers klantcontact werkzaam bij acht callcenters in de regio Arnhem/Nijmegen schriftelijk ondervraagd. In totaal hebben 525 medewerkers klantcontact meegewerkt. Dit betekent een respons van 48,3 procent. Op deze wijze is informatie verkregen over de arbeidsmarktsegmenten waarop callcenters hun medewerkers klantcontact rekruteren, de competenties en trainingsparticipatie van deze medewerkers en hun arbeidsmarktpositie. Daarnaast zijn aan managers van de acht callcenters enkele aanvullende vragen gesteld over specifieke bedrijfs- en functiekenmerken. De vragenlijsten voor de medewerkers klantcontact en voor de managers van de callcenters zijn in de bijlage achter in dit rapport te vinden. Er is gekozen voor juist deze acht callcenters, omdat zij van elkaar verschillen in de diensten die ze uitoefenen, het aantal medewerkers dat zij in dienst hebben en in de beloningsystemen die zij hanteren. Door de verschillende callcenters met elkaar te vergelijken, kan onderzocht worden of het arbeidsmarktsegment, de skill gaps en de loopbaanperspectieven kenmerkend zijn voor de callcenter sector in de regio 
Arnhem/Nijmegen in het algemeen, of mede afhankelijk zijn van het specifieke bedrijf.

\subsection{Opzet van dit rapport}

De verdere indeling van dit rapport is als volgt. In hoofdstuk 2 wordt eerst een algemene beschrijving gegeven van de acht callcenters die meegewerkt hebben aan dit onderzoek. Daarna volgt een beschrijving van de medewerkers klantcontact die bij deze bedrijven in het contact center werken. Wat is hun algemene achtergrond (geslacht, leeftijd, gezinssituatie en nevenactiviteiten) en wat zijn de aspecten die met hun werk te maken hebben (soort contract, werkervaring, werktijden, productiviteit en beloning)? Hiermee wordt een antwoord gegeven op de vraag op welke arbeidsmarktsegmenten callcenters hun medewerkers rekruteren.

In hoofdstuk 3 komen dan de opleidingsachtergronden en competenties van medewerkers klantcontact aan bod. Er wordt in kaart gebracht welke competenties de medewerkers nodig hebben om hun functie adequaat uit te kunnen oefenen, en in hoeverre zij deze competenties bezitten. Door na te gaan in hoeverre de opleidingsachtergronden van de werkenden aansluiten op de voor het werk vereiste competenties kunnen eventuele hiaten in kennis en vaardigheden, de zogenaamde skill gaps, vastgesteld worden.

Hoofdstuk 4 gaat in op de vraag hoe callcenters op deze skill gaps inspelen. Hierbij ligt de nadruk op de participatie in cursussen en trainingen. Welke cursussen volgen medewerkers klantcontact en waarom? Welke cursussen worden er door de callcenters aangeboden en aan welke cursussen hebben de medewerkers behoefte? En, hebben de gevolgde cursussen en trainingen bijgedragen aan het verkleinen van de aanwezige skill gaps? Hierbij wordt ook de rol die het leren op de werkplek heeft onderzocht.

In hoofdstuk 5 wordt de arbeidsmarktpositie van de medewerkers van de callcenters onderzocht. Wat zijn hun loopbaanperspectieven en hoe tevreden zijn zij over verschillende aspecten van hun werk? En in hoeverre spelen competenties van medewerkers een rol in het bepalen van hun arbeidsmarktpositie binnen en buiten de callcentersector?

De belangrijkste bevindingen van het onderzoek worden samengevat in het resumé dat voorin dit rapport te vinden is. 



\section{Callcenters en hun medewerkers}

\subsection{Inleiding}

In dit hoofdstuk staat de vraag centraal op welke arbeidsmarktsegmenten callcenters in de regio Arnhem/Nijmegen hun medewerkers klantcontact rekruteren. Om een antwoord op deze vraag te geven wordt allereerst een beschrijving gegeven van de acht callcenters in de regio Arnhem/Nijmegen die aan dit onderzoek meegewerkt hebben. Deze acht callcenters zijn uitgekozen omdat zij op belangrijke punten van elkaar verschillen. Zo verrichten zij uiteenlopende diensten, verschillen ze in omvang en hanteren ze verschillende beloningssystemen. Paragraaf 2.2 gaat in op deze verschillen op basis van informatie die door de managers van de callcenters verstrekt is.

Daarna volgt in paragraaf 2.3 een beschrijving van de medewerkers die in het zogenaamde contact center van deze acht callcenters werken. Het contact center is het hart van het callcenter. Hier vinden de telefonische gesprekken met klanten plaats. In deze paragraaf wordt een beeld geschetst van de medewerkers klantcontact op basis van hun algemene achtergrond, dat wil zeggen hun woonregio, geslacht, leeftijd, gezinssituatie en eventuele nevenactiviteiten ${ }^{2}$. Ook wordt aangegeven in hoeverre de acht callcenters van elkaar verschillen in het soort medewerkers dat zij aantrekken, dat wil zeggen of zij hun medewerkers op verschillende arbeidsmarktsegmenten rekruteren.

Ten slotte worden in paragraaf 2.4 diverse aspecten van het werk als medewerker klantcontact in de acht onderzochte callcenters beschreven. Het gaat daarbij om zaken als aard van de aanstelling, werkervaring, werktijden, productiviteit en beloning. Ook hierbij zal ingegaan worden op eventuele verschillen tussen de acht callcenters.

\subsection{De callcenters in dit rapport}

De acht benaderde callcenters in de regio Arnhem/Nijmegen verschillen van elkaar op een aantal belangrijke punten. Tabel 2.1 geeft een overzicht van deze verschillen. In de eerste plaats valt op dat zes van de acht callcenters een in-house contact center zijn, hetgeen wil zeggen dat het contact center onderdeel is van het bedrijf waarvoor het diensten verleent. In Nederland vormen in-house callcenters het grootste aandeel op de callcentermarkt, de schattingen lopen uiteen van 60 tot 80 procent (Braaksma, 1998). Omdat het center gevestigd is binnen de muren van het bedrijf, zullen medewerkers zich waarschijnlijk meer betrokken voelen bij het bedrijf en haar producten dan medewerkers van callcenters die in opdracht van andere bedrijven werken. Twee callcenters zijn een outsourcing contact center. Zij worden door bedrijven ingehuurd om diensten te verlenen. Het is aannemelijk dat de afstand

2. De opleidingsachtergrond van medewerkers klantcontact blijt hierbij buiten beschouwing Deze komt uitvoerig aan bod in het volgende hoofdstuk. 
tussen deze callcenters en het opdrachtgevende bedrijf niet alleen fysiek, maar ook psychisch groter is dan bij de in-house contact centers.

Tabel 2.1

Enkele kenmerken van de acht onderzochte callcenters in de regio Arnhem/Nijmegen

Kenmerk

Aantal callcenters

Soort contact center

In-house contact center

Outsourcing contact center

Telefonisch contact

Alleen inbound gesprekken

Zowel inbound als outbound gesprekken

Dienstverlening

Service

Verkoop / reserveringen / lead generation

Helpdesk

Klachtenafhandeling

Marktonderzoek

Databaseverrijking en controle

Aantal medewerkers klantcontact

Minder dan 100

Tussen de 100 en 150

Meer dan 150

Ziekteverzuim

Minder dan 8\%

8 tot $12 \%$

Meer dan $12 \%$

Beloningssysteem

Alleen een vast honorarium

Vast honorarium en prestatietoeslag

Vast honorarium en toeslag op bepaalde taken

Alleen op uur-basis

Toeslagen

Geen

Avonddienst

Weekenddienst

Feestdagen

In alle callcenters vinden telefonische gesprekken plaats die een inbound karakter hebben. Dit houdt in dat de klant zelf contact zoekt met het callcenter en daar te woord gestaan wordt door een medewerker. Bij outbound gesprekken is het de medewerker van het callcenter die de klant telefonisch benadert. Outbound gesprekken vinden in zes van de acht callcenters plaats. Dit betekent dat in zes van de onderzochte callcenters zowel inbound als outbound gesprekken gevoerd worden, terwijl in twee callcenters alleen inbound gesprekken plaatshebben.

De diensten die de callcenters verrichten zijn heel divers. Alle onderzochte callcenters richten zich op serviceverlening. Zeven van de acht callcenters zijn actief op het gebied van verkoop, reserveringen en het verwerven van zakelijke klanten (lead generation). Vier callcenters verzorgen een helpdesk, zes handelen klachten 
af, en drie houden zich bezig met databaseverrijking en controle. Geen van de onderzochte callcenters voert marktonderzoeken uit.

De acht onderzochte callcenters verschillen ook van elkaar qua grootte. Bij het kleinste callcenter werken 80 mensen, waaronder 65 medewerkers klantcontact. Het grootste callcenter heeft 600 werknemers in dienst, waarvan 550 telefonisch contact met klanten onderhouden. Uit cijfers van het NCCBP-onderzoek blijkt overigens dat callcenters in de regio Arnhem/Nijmegen relatief groot zijn in vergelijking met de rest van Nederland (NCCBP, 2001). Het ziekteverzuim in de acht callcenters ligt tussen de 8 en 12 procent, met één uitschieter omlaag van 4 procent en één uitschieter omhoog van 21 procent.

Ten slotte verschillen de beloningssystemen die de acht callcenters hanteren van elkaar. Drie callcenters geven hun medewerkers klantcontact alleen een vast honorarium. Eveneens drie callcenters betalen een vast honorarium plus een prestatietoeslag uit. Eén callcenter werkt met een vast honorarium en toeslagen voor bepaalde taken, een ander callcenter laat medewerkers klantcontact op uurbasis declareren. Bovendien werken vijf callcenters met toeslagen voor werktijden buiten kantooruren. Zo verdienen medewerkers klantcontact in twee callcenters 25 procent extra wanneer zij een avonddienst draaien. Een weekenddienst levert bij drie callcenters een toeslag op variërend van 25 tot 40 procent. Werken tijdens feestdagen wordt bij twee callcenters gehonoreerd met een dubbel salaris en door één callcenter met een drievoudig salaris. Voor reservediensten en stand-by diensten worden bij de acht onderzochte callcenters geen toeslagen uitbetaald.

\subsection{De achtergronden van medewerkers}

Om te kunnen nagaan op welke arbeidsmarktsegmenten callcenters hun medewerkers klantcontact rekruteren, kijken we allereerst naar de woonregio, geslacht, leeftijd, gezinssituatie en eventuele nevenactiviteiten van medewerkers.

\section{Woonregio}

Figuur 2.1

Enkele reistijd in minuten van medewerkers klantcontact

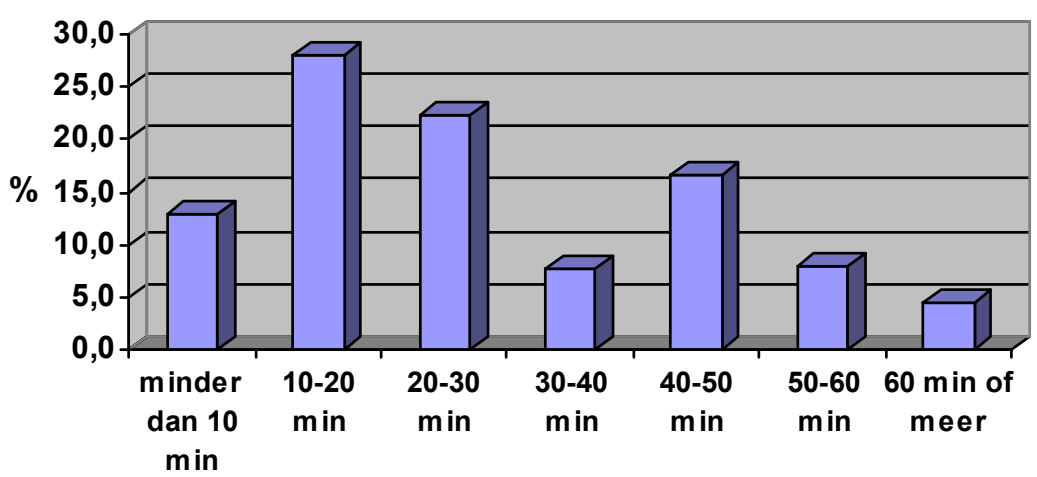


Figuur 2.1 laat zien dat callcenters hun medewerkers klantcontact in de nabije regio werven. De meeste medewerkers reizen in 10 tot 20 minuten naar hun werk. Slechts 5 procent woont op meer dan een uur reizen van het callcenter. De gemiddelde enkele reistijd van deur tot deur blijkt overigens 31 minuten te zijn. Er zijn geen verschillen in reistijd tussen de acht onderzochte callcenters gevonden. Ook zijn er op dit punt geen verschillen tussen mannen en vrouwen, jongere en oudere medewerkers en fulltimers en parttimers.

\section{Achtergrondkenmerken}

Tabel 2.2 geeft een overzicht van enkele achtergrondkenmerken van de medewerkers klantcontact. Uit deze tabel blijkt in de eerste plaats dat bij callcenters meer vrouwen dan mannen werkzaam zijn. Slechts bij twee callcenters zijn vrouwen in de minderheid, maar er zijn geen in het oog springende bedrijfskenmerken die dit verschil kunnen verklaren. Verder blijken callcenters vooral jonge werknemers te rekruteren. Maar liefst 43 procent van de medewerkers klantcontact is jonger dan 25 jaar; slechts één vijfde is ouder dan 40 jaar. De gemiddelde leeftijd van medewerkers klantcontact is overigens 30 jaar, zowel voor mannen als voor vrouwen. Eén bedrijf zit daar met een gemiddelde leeftijd van 22 jaar flink onder, terwijl twee bedrijven wat meer oudere werknemers in dienst hebben (gemiddelde leeftijd is respectievelijk 40 en 42 jaar).

Tabel 2.2

Enkele achtergrondkenmerken van medewerkers klantcontact

\begin{tabular}{lccc}
\hline Achtergrondkenmerk & $\begin{array}{c}\text { Man } \\
\%\end{array}$ & $\begin{array}{c}\text { Vrouw } \\
\%\end{array}$ & $\begin{array}{c}\text { Totaal } \\
\%\end{array}$ \\
\hline $\begin{array}{l}\text { Leeftijd tot } 25 \text { jaar } \\
\text { Leeftijd van 25 tot } 40 \text { jaar }\end{array}$ & 40 & 46 & 43 \\
Leeftijd boven de 40 jaar & 39 & 36 & 37 \\
Partner & 21 & 18 & 19 \\
Thuiswonende kind(eren) & 45 & 51 & 48 \\
Totaal & 24 & 31 & 28 \\
\hline
\end{tabular}

Tevens laat tabel 2.2 zien dat ongeveer de helft van de medewerkers klantcontact een partner heeft waarmee een gezamenlijke huishouding gevoerd worden. De meeste partners werken (85\%): mannen hebben meestal een voltijd baan, vrouwen werken parttime. Slechts enkele partners studeren $(5 \%)$ of verrichten huishoudelijk werk of zorgtaken (4\%); de rest is werkzoekend, arbeidsongeschikt of met pensioen $(4 \%)$. lets meer dan een kwart van de medewerkers klantcontact heeft één of meerdere thuiswonende kinderen. Bij de vrouwelijke medewerkers ligt dit percentage wat hoger dan bij de mannen. Gemiddeld genomen gaat het om 1,7 kind, waarbij de gemiddelde leeftijd van het jongste thuiswonende kind 10 jaar is. Een groot deel van de werkende vrouwen met kinderen (37\%) heeft zeer jonge thuiswonende kinderen, dat wil zeggen jonger dan 4 jaar. 38 procent van de werkende moeders heeft thuiswonende kinderen die tussen de 4 en 12 jaar oud zijn en dus op de basisschool 
zitten. Blijkbaar is het werken in een callcenter goed te combineren met de zorg voor (jonge) kinderen.

\section{Nevenactiviteiten}

Tabel 2.3 geeft aan dat een grote groep medewerkers vrije tijd als belangrijkste bezigheid naast het werk bij het callcenter ziet. Dit geldt met name voor diegenen die 32 uur per week of meer werken. Binnen de groep die minder dan 32 uur per week werkt zijn veel medewerkers nog scholier of student. Ook de zorg voor kinderen, huishoudelijk werk of andere zorgtaken blijkt een belangrijke nevenactiviteit te zijn. Een kleine groep medewerkers heeft een tweede baan naast hun werk bij het callcenter. Dit betreft meestal mensen die een eigen zaak hebben en die het werk in het callcenter gebruiken om hun (onzekere) inkomen aan te vullen. Bij de nevenactiviteiten die men heeft zijn er duidelijke verschillen tussen mannen en vrouwen. Mannelijke medewerkers klantcontact geven vaker aan dat vrije tijd hun belangrijkste nevenactiviteit is, terwijl vrouwen meer bezig zijn met zorgtaken. De verschillen tussen oudere en jongere medewerkers zijn niet zo groot, al besteden jongeren wel iets meer tijd aan school of studie. Toch zijn er ook onder de medewerkers ouder dan 40 jaar mensen zich bezighouden met een studie $(7 \%)$. Wellicht maakt het werk in het callcenter het voor hen financieel mogelijk om te kunnen studeren. Verder zijn ouderen iets meer bezig met zorgtaken en met een eventuele andere baan dan jongeren. Ook de verschillen in nevenactiviteiten van medewerkers die er tussen de callcenters bestaan, zijn grotendeels terug te voeren op de leeftijdsopbouw van het personeel.

Tabel 2.3

Nevenactiviteiten van medewerkers klantcontact in deeltijd, voltijd en totaal

\begin{tabular}{lccc}
\hline Nevenactiviteit & $\begin{array}{c}\text { Werkt minder dan } \\
32 \text { uur per week } \\
\%\end{array}$ & $\begin{array}{c}\text { Werkt 32 uur per } \\
\text { week of meer } \\
\%\end{array}$ & $\begin{array}{c}\text { Totaal } \\
\%\end{array}$ \\
\hline Vrije tijd & 27 & 68 & 45 \\
School of studie & 40 & 9 & 26 \\
Zorgtaken & 28 & 20 & 4 \\
Andere baan & 5 & 2 & 1 \\
Overig & 1 & 1 & \\
\hline
\end{tabular}

We kunnen dus stellen dat callcenters een waardevolle maatschappelijke functie vervullen. Zij bieden goede perspectieven voor werknemers die werk willen combineren met zorgtaken of het volgen van een opleiding. Voor de callcenters zelf betekent dit overigens ook dat men op deze segmenten van de arbeidsmarkt een sterke positie inneemt. Dit blijkt onder andere uit het feit dat een kwart van de medewerkers naast hun werk nog een opleiding volgen (tabel 2.3) en uit het vrij hoge percentage vrouwen met relatief jonge kinderen dat werkzaam is bij callcenters (tabel 2.2). 


\subsection{Aspecten van het werk als medewerker klantcontact}

\section{Aard van het contract}

Figuur 2.2 laat zien dat het leeuwendeel een vast contract (64\%) heeft of een tijdelijk contract met uitzicht op een vaste aanstelling (18\%). De verschillen tussen de onderzochte callcenters zijn niet zo groot, al is er één bedrijf waar veel werknemers met een tijdelijk contract werken en een ander bedrijf dat met name oproepkrachten in dienst heeft. Het gaat in beide gevallen om callcenters waar veel jongeren werkzaam zijn. Oudere werknemers blijken vaker een vast contract te hebben. Er zijn geen verschillen in de aard van de aanstelling tussen mannen en vrouwen te vinden.

Figuur 2.2

Soort contract van medewerkers klantcontact

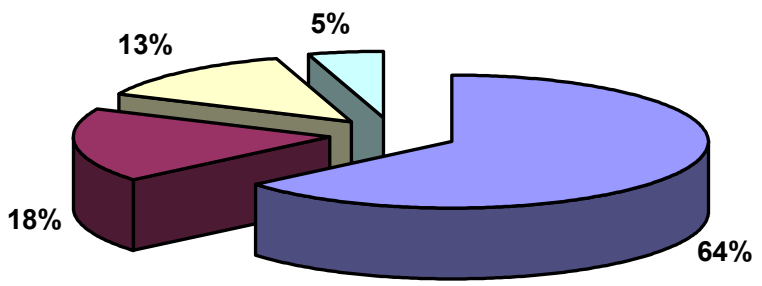

$\square$ vast contract

$\square$ tijdelijk met uitzicht op vast

$\square$ tijdelijk contract

口oproepbasis

\section{Werkervaring}

Tabel 2.4 geeft een overzicht van een aantal andere kenmerken van het werk als medewerker klantcontact. Over het algemeen zijn medewerkers klantcontact nog maar relatief kort bij hun huidige werkgever in dienst, namelijk gemiddeld 2 jaar en 2 maanden. Verschillende medewerkers zijn vóór hun huidige baan echter elders als medewerker klantcontact werkzaam geweest. De totale werkervaring bedraagt daardoor gemiddeld 3 jaar en 1 maand. Twee callcenters springen er in dit opzicht uit, omdat hun medewerkers een gemiddelde diensttijd van slechts 6 maanden hebben. Deze twee callcenters nemen met name jonge medewerkers met een tijdelijk contract of op oproepbasis in dienst. Callcenters die hun medewerkers een vast contract aanbieden zijn beter in staat hen langer in dienst te houden. Zo is de gemiddelde diensttijd bij een ander callcenter, waar relatief veel medewerkers met een vast contract werkzaam zijn, opmerkelijk langer: 9 jaar en 5 maanden. Overigens blijken oudere werknemers bij alle callcenters wat langer in dienst te zijn.

Tabel 2.4 geeft verder aan dat medewerkers klantcontact volgens hun contract gemiddeld ongeveer 30 uur per week werken ${ }^{3}$. Eén op de tien medewerkers werkt

3. Medewerkers klantcontact die op oproepbasis werken zijn hier niet meegeteld, omdat zij niet over een contract met een vast aantal werkuren per week beschikken. 
regelmatig meer uren per week dan in hun contract vastgelegd is. Het gaat dan in de helft van de gevallen om overwerk van 1 tot 4 uur per week. Medewerkers met een vast contract maken meer overuren dan medewerkers met een tijdelijk contract. Overigens werkt 3 procent van de medewerkers klantcontact minder uren per week dan in het contract staat.

Tabel 2.4

Enkele aspecten van het werk als medewerker klantcontact

Aspect

Aantal jaren in dienst bij callcenter

Aantal jaren werkervaring als medewerker klantcontact

Aantal werkuren per week volgens contract

Percentage medewerkers dat meer uren werkt dan in contract staat

Percentage medewerkers dat minder uren werkt dan contract staat

Percentage medewerkers dat meer uren wil werken

Percentage medewerkers dat minder uren wil werken

\section{Omvang werkweek}

Wat is volgens medewerkers klantcontact de ideale omvang van hun werkweek? Ongeveer 60 procent geeft te kennen precies evenveel uur per week te willen werken als zij feitelijk nu al doen. Een aanzienlijke groep (28\%) wil graag minder uren per week werken. In verreweg de meeste gevallen (70\%) 4 tot 8 uur per week minder. Opvallend genoeg bestaat er geen verschil tussen mannelijke en vrouwelijke medewerkers. Ook het hebben van een partner en thuiswonende kinderen heeft geen invloed op de wens om minder uren te werken. Medewerkers die graag meer uren per week willen werken (12\%) zijn meestal oproepkrachten. Zij werken over het algemeen relatief weinig, gemiddeld zo'n 16 uur per week.

Wanneer we kijken naar de verschillen tussen de acht onderzochte callcenters op dit punt, dan blijkt met name het bedrijf waar veel oproepkrachten werken een aparte positie in te nemen. Werknemers klantcontact werken hier relatief weinig uur per week, verrichten structureel overwerk en geven aan liefst nog meer uren te willen werken. Overigens blijken er geen verschillen in het feitelijk of gewenste aantal werkuren per week tussen mannen en vrouwen of tussen jongere en oudere werknemers te zijn.

\section{Onregelmatige diensten}

Aan de medewerkers klantcontact is ook gevraagd aan te geven wanneer zij werken. De meeste medewerkers blijken op regelmatige tijden te werken: 's ochtends (van 8.00 tot 13.00 ) en 's middags (van 13.00 tot 17.00). Sommige medewerkers werken ook een paar uur in de avond, maar 's nachts (van 21.00 tot 8.00 ) wordt er nauwelijks gewerkt. Figuur 2.3 laat zien dat bijna 60 procent van de medewerkers klantcontact wel eens in het weekend werkt, terwijl iets meer dan 40 procent op feestdagen werkt. Reservediensten komen veel minder vaak voor, en dan ook nog 
maar bij drie van de acht onderzochte callcenters. Een stand-by dienst is nog zeldzamer en wordt maar bij één bedrijf gedraaid.

Figuur 2.3

Soort werkdiensten van medewerkers klantcontact

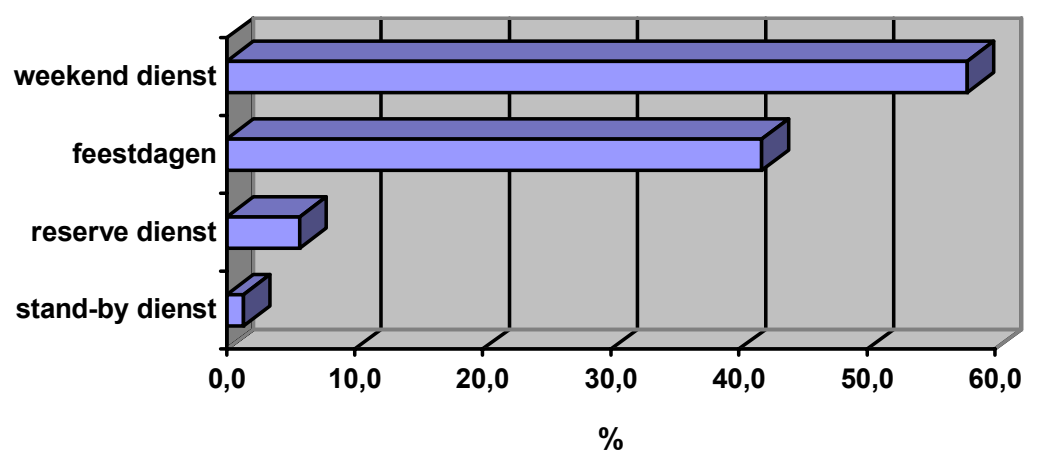

\section{Productiviteit}

Het aantal gesprekken dat een medewerker klantcontact gemiddeld per uur voert is een indicatie van de productiviteit, al moet daarbij wel rekening gehouden worden met het feit dat bepaalde gesprekken meer tijd kosten dan andere gesprekken.

Figuur 2.4

Soort gesprekken dat door medewerkers klantcontact gevoerd wordt

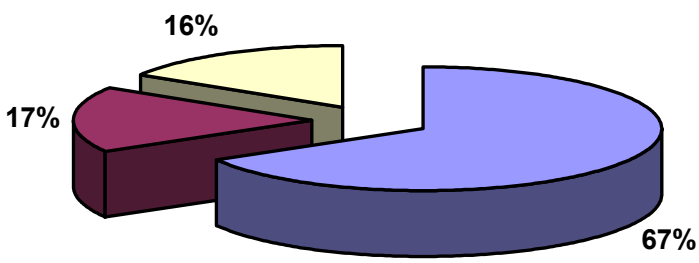

口alleen inbound

$\square$ alleen outbound

口beide

Medewerkers klantcontact handelen gemiddeld 11,7 gesprekken per uur af, al zijn er wel aanzienlijke verschillen tussen de acht onderzochte callcenters ${ }^{4}$. Inbound gesprekken, waarbij een klant naar het callcenter belt en daar te woord gestaan wordt, blijken meer tijd in beslag te nemen dan outbound gesprekken, waarbij een

4. Cijfers over het aantal afgehandelde gesprekken per uur dienen voorzichtig geïnterpreteerd te worden. Het betreft immers een schatting van de medewerkers zelf. Ongeveer 20 procent van de medewerkers klantcontact heeft hier ook geen antwoord op kunnen of willen gegeven. 
klant door een medewerker klantcontact gebeld wordt. Medewerkers klantcontact die alleen inbound gesprekken voeren handelen namelijk gemiddeld 10,8 gesprekken per uur af, terwijl dit gemiddelde voor medewerkers die alleen outbound gesprekken voeren op 17,4 ligt. De meeste gesprekken die gevoerd worden zijn overigens inbound van aard (zie figuur 2.4).

\section{Beloning}

De overgrote meerderheid van de medewerkers klantcontact $(72 \%)$ ontvangt een bruto uurloon dat tussen de fl. 15,- en fl. 26,- ligt. Bij een volledige werkweek van 36 uur zou dit neerkomen op een bruto maandloon tussen de fl. 2.340,- en de fl. 4.056,Het modale bruto uurloon van medewerkers klantcontact is overigens fl. 22,-hetgeen overeenkomt met een bruto maandloon van fl. 3.432,-. Eén callcenter blijft hier flink bij achter met een modaal bruto uurloon van fl. 11,- oftewel fl. 1.716,- bruto per maand. Dit heeft voornamelijk te maken met het feit dat bij dit bedrijf veel jongere werknemers en oproepkrachten in dienst zijn. Deze oproepkrachten verdienen gemiddeld minder dan werknemers met een vast of tijdelijk contact. Tussen mannen en vrouwen is er geen verschil in bruto uurloon. Opmerkelijk is wel dat er een negatief verband bestaat tussen inkomen en productiviteit. In callcenters waar hogere beloningen betaald worden, is het aantal gesprekken dat per uur afgehandeld wordt lager. Wellicht zijn gesprekken die meer tijd in beslag nemen, moeilijker van aard en betalen callcenters de medewerkers klantcontact die deze gesprekken voeren daarom meer. 



\section{Opleiding en competenties van medewerkers}

\subsection{Inleiding}

De kennis en vaardigheden, waarover mensen beschikken, bepalen of ze een functie adequaat kunnen vervullen. Callcenters zullen daarom óf mensen moeten aantrekken die over de juiste competenties beschikken, óf de competenties van hun medewerkers op peil moeten brengen door te investeren in aanvullende cursussen en on-the-job training.

In dit hoofdstuk zullen we de competenties van medewerkers klantcontact, die werkzaam zijn bij de acht onderzochte callcenters, in kaart brengen. In paragraaf 3.2 wordt eerst de algemene opleidingsachtergrond van de medewerkers beschreven, dat wil zeggen hun opleidingsniveau, opleidingsrichting en beheersing van vreemde talen.

Daarna wordt in paragraaf 3.3 gekeken naar de competenties die nodig zijn om de functie van medewerker klantcontact bij een callcenter goed te kunnen vervullen. We onderscheiden hierbij 13 competenties, waaronder meer algemenere competenties als computervaardigheden, talenkennis en probleemoplossend vermogen en meer specifiekere competenties als telefonische verkooptechniek, bedrijfskennis en productkennis. Aan de medewerkers klantcontact is gevraagd hoe belangrijk deze competenties voor het goed vervullen van hun functie zijn. Daarnaast hebben ook de managers van de acht onderzochte callcenters aangegeven hoe belangrijk zij de 13 competenties achten voor het goed vervullen van deze functie. Beide metingen worden in paragraaf 3.3 naast elkaar gelegd.

Ten slotte wordt in paragraaf 3.4 onderzocht over welke kennis en vaardigheden de medewerkers klantcontact naar eigen zeggen beschikken. Door middel van een zelfbeoordeling is vast te stellen in hoeverre de genoemde competenties bij de medewerkers van de acht onderzochte callcenters aanwezig zijn. Hiermee kunnen eventuele hiaten in kennis en vaardigheden, de zogenaamde skill gaps, opgespoord worden en kan een antwoord geformuleerd worden op de vraag in hoeverre de opleidingsachtergronden aansluiten bij de voor het werk vereiste competenties.

\subsection{Opleidingsachtergrond van medewerkers}

Figuur 3.1 laat zien dat de meeste medewerkers klantcontact een MBO diploma hebben (34\%). Een HAVO of MBO diploma blijkt overigens niet de minimaal vereiste startkwalificatie te zijn om als medewerker klantcontact bij een callcenter aan de slag te kunnen. Maar liefst 20 procent van de werkenden heeft een lager opleidingsniveau. De acht onderzochte callcenters verschillen van elkaar wat het opleidingsniveau van hun medewerkers klantcontact betreft. Twee bedrijven hebben beduidend meer hoger opgeleiden in dienst, terwijl bij drie bedrijven opvallend veel lager opgeleiden werkzaam zijn. Dit heeft vooral te maken met de leeftijdsopbouw van het personeel: jongere werknemers zijn hoger opgeleid dan oudere werknemers. Er zijn 
geen verschillen in opleidingsniveau tussen mannelijke en vrouwelijke medewerkers klantcontact, of tussen medewerkers met een vast, tijdelijk of oproepbasis contract.

Figuur 3.1

Opleidingsniveau van medewerkers klantcontact

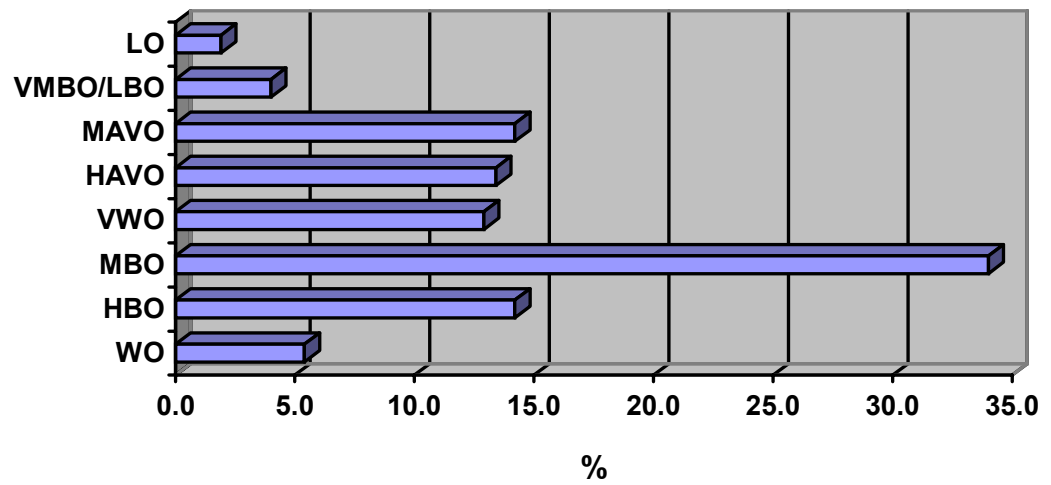

De laatste kolom in tabel 3.1 laat zien dat bijna de helft van alle medewerkers klantcontact geen beroepsopleiding heeft afgerond, maar beschikt over een 'algemene' opleidingsachtergrond. Bijna 30 procent heeft de opleidingsrichting 'economie en administratie' gevolgd. Ook de richtingen 'gezondheidszorg' en 'techniek' komen opmerkelijk vaak voor, met name op MBO-niveau. De HBO'ers en WO'ers hebben, naast de richting 'economie en administratie', veelal een richting 'gedrag en maatschappij', 'kunst en cultuur' of 'onderwijs' gevolgd. Uit dit brede pallet aan opleidingsrichtingen zou geconcludeerd kunnen worden dat callcenters bij het werven van hun personeel niet zo letten op de feitelijk gevolgde opleiding, al lijkt een 'economische en administratieve' opleiding op MBO-niveau de voorkeur te hebben. Maar liefst 20 procent van de medewerkers klantcontact heeft een dergelijke opleiding afgesloten. Eerder onderzoek wees ook al uit dat erg geen specifieke opleidingseisen gehanteerd worden bij het aannemen van nieuw personeel (Eimers \& Thomas, 2000).

Tabel 3.1

Opleidingsrichting van medewerkers klantcontact per opleidingsniveau

\begin{tabular}{lccrrr}
\hline Opleidingsrichting & $\begin{array}{c}\text { LO/VMBO/ } \\
\text { LBO } \\
\%\end{array}$ & $\begin{array}{c}\text { MAVO/HAVO/ } \\
\text { VWO } \\
\%\end{array}$ & $\begin{array}{c}\text { MBO } \\
\%\end{array}$ & $\begin{array}{c}\text { HBO/WO } \\
\%\end{array}$ & $\begin{array}{c}\text { Totaal } \\
\%\end{array}$ \\
\hline Algemeen & 47 & 100 & 9 & - & 47 \\
Economie en administratie & 20 & - & 59 & 37 & 28 \\
Gezondheidszorg & 23 & - & 13 & 8 & 7 \\
Techniek & 10 & - & 11 & 5 & 4 \\
Gedrag en maatschappij & - & - & 2 & 15 & 4 \\
Kunst en cultuur & - & - & 2 & 11 & 3 \\
Onderwijs & - & - & 1 & 5 & 1 \\
Recht en openbare orde & - & - & - & 5 & 1 \\
Natuurwetenschappen & - & - & 1 & 2 & 100 \\
Landbouw & 100 & 100 & 100 & 100 & 100 \\
Totaal & & & &
\end{tabular}


Hierbij moet wel opgemerkt worden dat van medewerkers klantcontact waarschijnlijk steeds vaker verwacht zal worden dat zij over minimaal een MBO-opleiding beschikken. Niet alleen vanwege de toenemende complexiteit van hun werkzaamheden, maar ook het feit dat het merendeel van de klanten een opleiding op MBO-niveau of hoger gevolgd heeft, is hier debet aan. In de toekomst zullen callcenters dan ook steeds vaker medewerkers klantcontact met een MBO-opleiding of hoger moeten werven.

De regio Arnhem/Nijmegen beschikt over een aanzienlijk hoog opgeleid arbeidspotentieel. Uit cijfers van het CBS blijkt dat ongeveer 12.700 leerlingen in de regio Arnhem/Nijmegen een $\mathrm{MBO}$ opleiding volgen (CBS, 2001). Hiervan heeft ongeveer $30 \%$ de richting 'economie en administratie' gekozen, die onder medewerkers klantcontact zo populair is. Daarnaast studeren in de regio Arnhem/Nijmegen maar liefst 18.000 studenten aan een HBO-instelling en 12.000 aan een universiteit. Dat deze twee groepen de weg naar het callcenter weten te vinden, volgt niet alleen uit de hier gepresenteerde cijfers ( zie figuur 3.1 waaruit blijkt dat één op de vijf medewerkers klantcontact een HBO of WO opleiding afgerond heeft). Ook het NCCBP-onderzoek geeft aan dat callcenters in de regio Arnhem/Nijmegen relatief veel $\mathrm{HBO}$-ers en universitair geschoolden in dienst hebben, vergeleken met callcenters in de rest van Nederland (NCCBP, 2001). De genoemde leerlingen- en studentenaantallen bieden dus goede perspectieven voor de toekomstige werving van medewerkers klantcontact in de regio Arnhem/Nijmegen.

\section{Talenkennis}

Omdat er in vier van de acht callcenters internationale gesprekken gevoerd worden, is er apart gevraagd naar de beheersing van vreemde talen. Engels wordt door medewerkers klantcontact - volgens eigen zeggen - goed beheerst. Duits en vooral Frans beheersen zij minder. Bij callcenters waar internationale gesprekken plaatsvinden, is talenkennis van groot belang. Dit blijkt uit het feit dat medewerkers, die bij deze callcenters in dienst zijn, beduidend beter in Engels zijn dan medewerkers die elders werken. Verschillen tussen beheersing van het Duits en Frans zijn niet gevonden. Deze verschillen zijn gedeeltelijk terug te voeren op het feit dat de genoemde vier callcenters over het algemeen ook hoger opgeleid personeel in dienst hebben. Hoger opgeleiden blijken Engels en Frans (maar niet Duits) beter te beheersen dan lager opgeleiden. Verder scoren vrouwelijke medewerkers hoger op hun beheersing van het Engels dan mannen. Hetzelfde geldt voor oproepkrachten ten opzichte van medewerkers met een vast contract. Ook de jongere medewerkers zijn beter in Engels dan oudere medewerkers. Oudere medewerkers zijn daarentegen weer beter in Duits dan jongeren. Overigens geven sommige medewerkers klantcontact aan nog andere talen te beheersen. Het gaat dan met name om Spaans, maar ook Turks, Italiaans, Arabisch en Surinaams worden genoemd. 
Tabel 3.2

Beheersing van vreemde talen van medewerkers klantcontact (driepuntsschaal: $1=$ slecht; 2=redelijk; 3=goed)

\begin{tabular}{lccc}
\hline Taal & Lezen & Spreken & Schrijven \\
\hline Engels & 2,7 & 2,5 & 2,4 \\
Duits & 2,2 & 2,0 & 1,7 \\
Frans & 1,3 & 1,3 & 1,2 \\
\hline
\end{tabular}

\subsection{Competenties}

Om na te gaan welke kennis en vaardigheden er nodig zijn voor het adequaat vervullen van de functie van medewerker klantcontact, zijn er twee wegen bewandeld. Allereerst is aan de medewerkers gevraagd wat zij menen dat het belang is van 13 competenties voor het goed vervullen van hun functie. Deze competenties zijn zowel algemeen van aard (bijvoorbeeld probleemoplossend vermogen, computervaardigheden en talenkennis) als meer specifiek op het werken in callcenters gericht (bijvoorbeeld product- en bedrijfskennis). De eerste twee kolommen van tabel 3.3 geven een overzicht van het belang van deze competenties volgens de medewerkers zelf. Aan de managers van de acht callcenters is dezelfde vraag gesteld: hoe belangrijk zijn deze kennis en vaardigheden voor het goed vervullen van de functie van medewerker klantcontact? De laatste twee kolommen in tabel 3.3 presenteren deze uitkomsten.

Tabel 3.3

Gemiddeld belang dat medewerkers klantcontact en managers hechten aan verschillende competenties voor het goed vervullen van de functie van medewerker klantcontact (vijfpuntsschaal van 1 tot en met 5)

\begin{tabular}{|c|c|c|c|c|}
\hline \multirow[t]{2}{*}{ Competentie } & \multicolumn{2}{|c|}{ Medewerkers } & \multicolumn{2}{|c|}{ Managers } \\
\hline & Score & Rangorde & Score & Rangorde \\
\hline \multicolumn{5}{|l|}{ Algemeen } \\
\hline Probleemoplossing & 4,5 & (3) & 4,2 & (5) \\
\hline Stressbeheersing & 4,1 & $(10)$ & 3,7 & $(10)$ \\
\hline Omgaan met kwaadheid en agressie & 4,2 & (8) & 3,8 & (7) \\
\hline Onderhandelingstechnieken & 3,6 & $(11)$ & 2,6 & (13) \\
\hline Motivatie & 4,4 & (5) & 3,8 & (9) \\
\hline Computervaardigheden & 4,3 & (6) & 4,7 & (3) \\
\hline Talenkennis & 3,6 & $(12)$ & 2,9 & $(12)$ \\
\hline \multicolumn{5}{|l|}{ Specifiek voor werk in callcenters } \\
\hline Klantgerichtheid & 4,7 & $(1)$ & 4,9 & (1) \\
\hline Productkennis & 4,5 & (4) & 4,7 & (2) \\
\hline Bedrijfskennis & 4,1 & (9) & 4,0 & (6) \\
\hline Basisgesprekstechnieken & 4,6 & $(2)$ & 4,4 & (4) \\
\hline Werkprocedures & 4,3 & (7) & 3,4 & (11) \\
\hline Telefonische verkooptechniek & 3,4 & (13) & 3,8 & (8) \\
\hline
\end{tabular}

Zowel medewerkers als managers blijken 'klantgerichtheid' de belangrijkste competentie voor het adequaat vervullen van de functie van medewerker klantcontact te vinden. Verder zijn de eveneens specifiek op callcenters gerichte 
competenties 'productkennis' en 'basisgesprekstechnieken' van groot belang, gevolgd door de meer algemene competenties 'probleemoplossing' en 'computervaardigheden'.

Er zijn overigens enkele opvallende verschillen tussen medewerkers en managers in de beoordeling van de belangrijkheid van competenties. Zo vinden managers 'productkennis' de op één na belangrijkste competentie waarover medewerkers klantcontact moeten beschikken, terwijl de medewerkers zelf deze competentie op de vierde plaats zetten ${ }^{5}$. Het omgekeerde geldt voor de competentie 'probleemoplossing', die juist door medewerkers belangrijker gevonden wordt dan door managers. Mogelijk zijn de managers meer gericht op het belang van productkennis voor een goede dienstverlening en zijn ze minder goed op de hoogte met de concrete problemen, die medewerkers tijdens hun werk ondervinden.

Natuurlijk worden, afhankelijk van het soort werkzaamheden dat medewerkers klantcontact bij een callcenter moeten uitvoeren, bepaalde competenties in het ene callcenter belangrijker gevonden dan in het andere. Grote verschillen in het belang van bepaalde competenties doen zich met name bij 'probleemoplossing' en 'talenkennis' voor. In het callcenter waar probleemoplossend vermogen minder belangrijk gevonden wordt voor het adequaat uitvoeren van de functie van medewerker klantcontact worden opmerkelijk genoeg alleen inbound gesprekken gevoerd. Bovendien werken er in dit callcenter veel laag opgeleide en oudere medewerkers klantcontact. De belangrijkheid van de competentie 'talenkennis' houdt duidelijk verband met het al dan niet voeren van internationale gesprekken in callcenters.

\subsection{Skill gaps}

$\mathrm{Nu}$ bekend is welke competenties nodig zijn voor het goed vervullen van de functie van medewerker klantcontact, kan nagegaan worden in hoeverre medewerkers van de acht onderzochte callcenters deze kennis en vaardigheden bezitten, en of er sprake is van competentietekorten oftewel skill gaps.

\section{Beoordeling van eigen competenties}

Tabel 3.4 laat zien hoe medewerkers klantcontact zichzelf beoordeeld hebben op de 13 competenties. Wat opvalt aan deze zelfbeoordeling is dat medewerkers klantcontact over het algemeen goed scoren op de competenties die het belangrijkst zijn voor het vervullen van hun functie, namelijk 'klantgerichtheid', 'basisgesprekstechnieken', 'probleemoplossing' en 'computervaardigheden'. Alleen de competentie 'productkennis' beheersen zij naar eigen zeggen minder goed.

5. Hierbij moet wel opgemerkt worden dat de belangrijkheidsscores voor productkennis in absolute zin niet veel verschillen tussen medewerkers en managers. 
Tabel 3.4

Eigen competentiebeoordeling van medewerkers klantcontact

\begin{tabular}{lccc}
\hline Competentie & $\begin{array}{c}\text { Matig tot slecht } \\
\%\end{array}$ & $\begin{array}{c}\text { Voldoende } \\
\%\end{array}$ & $\begin{array}{c}\text { Goed } \\
\%\end{array}$ \\
& & & 46 \\
Algemeen & & 50 & 46 \\
Probleemoplossing & 5 & 50 & 46 \\
Stressbeheersing & 4 & 47 & 22 \\
Omgaan met kwaadheid en agressie & 7 & 59 & 59 \\
Onderhandelingstechnieken & 18 & 35 & 27 \\
Motivatie & 6 & 45 & 65 \\
Computervaardigheden & 4 & 52 & 30 \\
Talenkennis & 21 & & 20 \\
Specifiek voor werk in callcenters & & 32 & 56 \\
Klantgerichtheid & 3 & 58 & 37 \\
Productkennis & 12 & 62 & 19 \\
Bedrijfkennis & 18 & 43 & 57 \\
Basisgesprekstechnieken & 2 & 58 & \\
Werkprocedures & 8 & & \\
Telefonische verkooptechniek & 33 & & \\
& & 48 & \\
\hline
\end{tabular}

Er zijn op dit punt overigens duidelijke verschillen tussen de verschillende callcenters, met name wat de competenties 'talenkennis', 'computervaardigheden', 'probleemoplossing' en 'telefonische verkooptechniek betreft. Mannelijke medewerkers blijken beter in 'onderhandelingstechnieken', 'probleemoplossing' en 'productkennis' te zijn. Vrouwelijke medewerkers scoren op hun beurt beduidend hoger op 'motivatie' en 'klantgerichtheid'. Ook wat leeftijd betreft zijn er verschillen in de competenties waarover men beschikt. Jongeren zeggen beter te zijn in 'computervaardigheden' en 'talenkennis', ouderen in 'klantgerichtheid' en 'bedrijfskennis'. Het is zeer opmerkelijk hoe weinig competentieverschillen er bestaan tussen hoger en lager opgeleiden, al moet wel bedacht worden dat iemands opleidingsniveau ook sterk bepalend kan zijn voor iemands ambitieniveau op een bepaald punt. Lager opgeleiden scoren slechter op 'basisgesprekstechnieken' en 'talenkennis' dan hoger opgeleiden, maar andere competentieverschillen zijn er niet gevonden. In dit opzicht is het eerder gevonden gegeven, dat opleidingsachtergrond geen doorslaggevende factor is bij de werving van personeel in callcenters, dan ook niet zo vreemd. De voor het werk relevante competenties hangen slechts in zeer beperkte mate samen met het opleidingsniveau van de medewerkers klantcontact.

\section{Skill gaps}

Om van een skill gap te kunnen spreken, moet er sprake zijn van een hiaat in de kennis en vaardigheden van een medewerker. Dit betekent dat iemand matig of slecht scoort op een competentie, die belangrijk is voor het adequaat vervullen van de functie die men uitoefent. Immers, wanneer een medewerker slecht is in talen, maar geen internationale gesprekken hoeft te voeren, dan is er geen probleem en hoeven we niet te spreken van een skill gap. Omdat de belangrijkheid van de diverse competenties verschilt tussen de acht onderzochte callcenters, hebben we het belang dat de manager van het betreffende callcenter aan een bepaalde competentie hecht gerelateerd aan de mate waarin medewerkers klantcontact die competentie 
beheersen. Zo ontstaat een maatstaf die aangeeft of medewerkers geen, een kleine of een grote skill gap hebben.

Tabel 3.5

Tekorten of skill gaps van medewerkers klantcontact op 13 competenties

\begin{tabular}{lccc}
\hline Skill gap & $\begin{array}{c}\text { Geen } \\
\%\end{array}$ & $\begin{array}{c}\text { Klein } \\
\%\end{array}$ & $\begin{array}{c}\text { Groot } \\
\%\end{array}$ \\
\hline $\begin{array}{l}\text { Algemeen } \\
\text { Probleemoplossing }\end{array}$ & & \\
Stressbeheersing & 95 & 2 & 3 \\
Omgaan met kwaadheid en agressie & 96 & 2 & 2 \\
Onderhandelingstechnieken & 94 & 17 & 4 \\
Motivatie & 92 & 2 & 4 \\
Computervaardigheden & 94 & 0 & 4 \\
Talenkennis & 95 & 18 & 3 \\
Specifiek voor werk in callcenters & 76 & & \\
Klantgerichtheid & & 0 & 3 \\
Productkennis & 97 & 1 & 12 \\
Bedrijfskennis & 88 & 0 & 2 \\
Basisgesprekstechnieken & 82 & 5 & 4 \\
Werkprocedures & 99 & 20 & 13 \\
Telefonische verkooptechniek & 92 & & \\
& 67 & & \\
\hline
\end{tabular}

Over het algemeen vallen de skill gaps bij medewerkers klantcontact in callcenters mee. Slechts een beperkt aantal medewerkers heeft te maken met een groot competentietekort (zie tabel 3.5). Enkele competenties springen er in dit opzicht echter uit. Zo blijkt éénderde van de medewerkers tekort te schieten op de competentie 'telefonische verkooptechniek'. Ook de competenties 'productkennis' en 'bedrijfskennis' leveren bij respectievelijk 12 en 18 procent van de medewerkers klantcontact grote skill gaps op. Kleinere skill gaps bestaan er voor de meer algemenere competenties 'onderhandelingstechnieken' en 'talenkennis'. De verschillen tussen de verschillende callcenters in de mate waarin hun personeel met skill gaps kampt, zijn aanzienlijk. Zo heeft één callcenter beduidend meer werknemers in dienst met een groot skill gap in 'computervaardigheden' (10 procent). Bij een ander callcenter werkt 17 procent van de medewerkers met een groot skill gap wat probleemoplossend vermogen betreft. Beide callcenters hebben relatief veel laag opgeleiden en ouderen in dienst. Dit hoeft echter niet te betekenen dat bedrijven met veel hoog opgeleide en jongere medewerkers klantcontact in dienst gevrijwaard blijven van grote skill gaps. Zo blijkt een callcenter met veel jonge, hoog opgeleide werknemers, relatief veel medewerkers te hebben met grote skill gaps in 'telefonische verkooptechniek' (50\%), 'motivatie' (27\%), 'talenkennis' (13\%), 'omgaan met kwaadheid en agressie' (13\%) en 'werkprocedures' (11\%).

Welke medewerkers klantcontact hebben nu het meest te maken met deze skill gaps? Dit wordt onderzocht door in een multivariate analyse verschillende kenmerken van medewerkers op te nemen. Het gaat dan om geslacht, leeftijd, werkervaring, in voltijd of deeltijd werken, het voeren van inbound of outbound 
gesprekken, opleidingsniveau en opleidingsrichting ${ }^{6}$. Ook worden kenmerken van de acht onderzochte callcenters bekeken, namelijk of het in-house of outsourcing callcenter is en het aantal medewerkers klantcontact in het bedrijf. De belangrijkste factoren voor het al dan niet ${ }^{7}$ hebben van de vijf grootste skill gaps staan vermeld in figuur 3.6.

Figuur 3.6

Belangrijkste factoren voor het hebben van competentietekorten of skill gaps van medewerkers klantcontact

\section{Skill gaps in:}
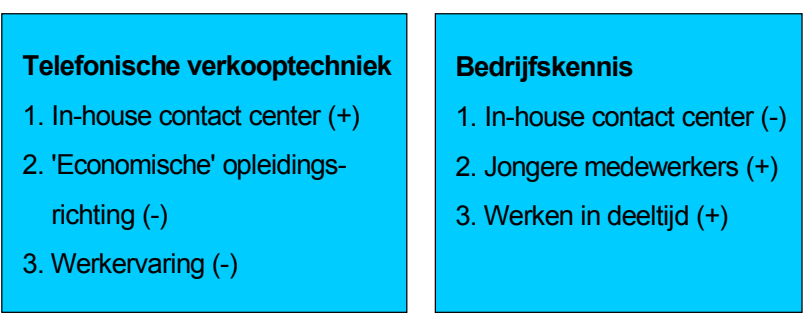
Productkennis
1. Werkervaring (-)
2. In-house contact center (-)
3. Vrouwen $(+)$

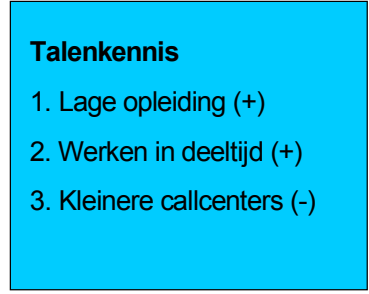

Onderhandelingstechnieken

1. Algemene opleidingsrichting (-)

2. Lage opleiding $(+)$

3. Werken in deeltijd $(+)$

'+' betekent grotere kans op skill gap; '-' betekent kleinere kans op skill gap

Uit deze figuur blijkt dat skill gaps in 'telefonische verkooptechniek' vaker voorkomen in callcenters met een in-house contact center. Medewerkers klantcontact, die over een afgeronde opleiding 'economie en administratie' beschikken, hebben het minst vaak een competentietekort op dit punt. Blijkbaar worden tijdens deze opleidingen veel commerciële vaardigheden aangeleerd, die van pas komen in het werk als medewerker klantcontact. Daarnaast hebben medewerkers met veel werkervaring minder last van een skill gap in 'telefonische verkooptechniek'. Dit duidt erop dat deze vaardigheid voor een groot deel ook op de werkplek aangeleerd wordt.

Bij de andere specifiek op het werk in een callcenter gerichte competenties, namelijk 'bedrijfskennis' en 'productkennis', schieten medewerkers die in een outsourcing

6. Soort contract is in deze analyse niet meegenomen, omdat dit zeer samenhangt met de werkervaring van medewerkers klantcontact.

7. Hierbij zijn de categorieën 'kleine skill gap' en 'grote skill gap' samengevoegd. 
contact center werken juist meer tekort dan medewerkers die in een in-house contact center werken. Wellicht voelt deze laatste groep werknemers zich meer betrokken bij het bedrijf en de producten, en is zij ook meer gemotiveerd om eventuele competentietekorten in bedrijfs- en productkennis weg te werken, bijvoorbeeld door het volgen van aanvullende cursussen. Op dit punt komen in het volgende hoofdstuk terug, wanneer we kijken naar de wijzen waarop skill gaps opgelost kunnen worden. Opvallend in dit opzicht is dat werkervaring de kans op een skill gap in 'productkennis' ook aanzienlijk vermindert.

Misschien niet geheel verwonderlijk is dat skill gaps in de meer algemene competenties 'talenkennis' en 'onderhandelingstechnieken' vaker voorkomen bij lager opgeleiden dan bij hoger opgeleiden. Ook medewerkers klantcontact die in deeltijd werken, hebben vaker met deze algemene skill gaps te maken. 



\section{Inspelen op skill gaps}

\subsection{Inleiding}

In het vorige hoofdstuk is geconstateerd dat medewerkers kantcontact vaak hiaten in hun kennis en vaardigheden vertonen, en met name in de competenties 'telefonische verkooptechniek', 'bedrijfskennis', productkennis', 'talenkennis' en 'onderhandelingstechnieken'. Deze skill gaps kunnen op verschillende manieren opgelost worden. Zo zouden medewerkers klantcontact met skill gaps op zoek kunnen gaan naar een andere baan waarin hun competenties beter aansluiten op hun functie. Callcenters kunnen werknemers met een tijdelijke aanstelling die grote skill gaps hebben ontslaan en hiervoor in de plaats nieuwe medewerkers die wel de benodigde competenties hebben aannemen. Met de huidige krapte op de arbeidsmarkt ligt deze laatste oplossing echter niet voor de hand. Bovendien beschikken mensen die nieuw worden aangetrokken welhaast per definitie over te weinig bedrijfs- en productkennis, competenties waaraan door de managers juist veel waarde wordt gehecht. De enige, realistische oplossing om skill gaps in callcenters weg te werken ligt in het vergroten van het menselijk kapitaal van medewerkers klantcontact. Door te investeren in aanvullende scholing kan de kennis en vaardigheden van medewerkers op peil gebracht worden.

In dit hoofdstuk ligt de nadruk dan ook op de deelname van medewerkers klantcontact aan cursussen en trainingen. Eerst wordt in paragraaf 4.2 beschreven welke cursussen en trainingen er door de acht onderzochte callcenters aangeboden worden en welke cursussen de medewerkers in het afgelopen jaar gevolgd hebben. Tevens wordt er een antwoord gegeven op de vraag welke medewerkers vooral deelnemen aan cursussen en trainingen.

Daarna wordt in paragraaf 4.3 ingegaan op de motieven die de medewerkers klantcontact hebben om cursussen en trainingen te volgen. Ook wordt onderzocht of de gevolgde cursussen en trainingen gezorgd hebben voor het verkleinen van de skill gaps bij medewerkers klantcontact, of dat juist het leren op de werkplek dit bewerkstelligd heeft.

Ten slotte wordt in paragraaf 4.4 ingegaan op de vraag of medewerkers klantcontact in de nabije toekomst nog scholing willen gaan volgen en de vraag of medewerkers met grote skill gaps hier meer behoefte aan hebben? En, hoe tevreden zijn medewerkers klantcontact over de scholingsfaciliteiten en de begeleiding op de werkplek?

\subsection{Deelname aan cursussen}

Uit tabel 4.1 blijkt dat alle acht onderzochte callcenters cursussen en trainingen aanbieden, met name cursussen die specifiek gericht zijn op het werk als medewerker klantcontact. Algemene cursussen worden veel minder vaak aangeboden, met uitzondering van computervaardigheidscursussen. De laatste kolom in tabel 4.1 laat zien dat 63 procent van de medewerkers klantcontact het afgelopen jaar een cursus 
of training gevolgd heeft. Ook hierbij geldt dat dit met name specifieke cursussen zijn. Zo heeft ongeveer éénderde van de medewerkers het afgelopen jaar deelgenomen aan cursussen 'productkennis' en 'basisgesprekstechnieken'. Ook de algemene cursus 'computervaardigheden' is populair. Een aantal medewerkers klantcontact (ongeveer 6\%) geeft aan nog andere cursussen te volgen. Het gaat dan met name om cursussen waar management aspecten zoals leidinggeven en coaching centraal staan, of om communicatietrainingen.

Tabel 4.1

Cursussen aangeboden door callcenters en het percentage medewerkers klantcontact dat het afgelopen jaar cursussen gevolgd heeft

$\begin{array}{ccc}\text { Cursus } & \begin{array}{c}\text { Aantal callcenters dat } \\ \text { cursus aanbiedt }\end{array} & \begin{array}{c}\text { Percentage medewerkers } \\ \text { dat cursus gevolgd heeft }\end{array}\end{array}$

Algemeen

Probleemoplossing

Stressbeheersing

Omgaan met kwaadheid en agressie

Onderhandelingstechnieken

Motivatie

Computervaardigheden

Talenkennis

Specifiek voor werk in callcenters

Klantgerichtheid

Productkennis

Bedrijfskennis

Basisgesprekstechnieken

Werkprocedures

Telefonische verkooptechniek cursus aanbiedt dat cursus gevolgd heeft

Totaal

$\begin{array}{lr}4 & 21 \\ 0 & 5 \\ 3 & 15 \\ 1 & 9 \\ 0 & 8 \\ 8 & 35 \\ 1 & 4\end{array}$

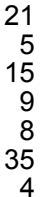

$\begin{array}{ll}6 & 25 \\ 8 & 33 \\ 2 & 22 \\ 8 & 30 \\ 6 & 24 \\ 7 & 19 \\ 8 & 63\end{array}$

Tussen de acht onderzochte callcenters bestaan grote verschillen in de deelname aan cursussen en trainingen van medewerkers klantcontact. Zo zijn er twee callcenters waar slechts een kwart van de medewerkers het afgelopen jaar een cursus gevolgd heeft. Drie andere callcenters geven hun medewerkers juist ruim baan om cursussen te volgen: hier heeft meer dan 80 procent het afgelopen jaar een cursus gevolgd. Dit heeft niet zozeer te maken met het aanbod van cursussen, want bij alle onderzochte callcenters hebben medewerkers klantcontact de keuze uit 6 tot 8 cursussen. Toch is het ene callcenter blijkbaar meer bereid om in cursussen en trainingen te investeren dan het andere.

Dat de deelname van medewerkers klantcontact aan cursussen afhangt van het callcenter waarin zij werkzaam zijn, blijkt ook wanneer we nagaan welke medewerkers klantcontact nu vaker cursussen en trainingen volgen dan anderen. In een multivariate analyse wordt gekeken naar kenmerken van medewerkers (geslacht, leeftijd, werkervaring, in voltijd of deeltijd werken, het voeren van inbound of outbound gesprekken, opleidingsniveau en opleidingsrichting) en naar kenmerken van de acht onderzochte callcenters (of het in-house of outsourcing callcenter betreft en het aantal medewerkers klantcontact in het bedrijf). Het blijkt dat alleen bedrijfskenmerken belangrijk zijn voor de deelname van medewerkers aan cursussen 
en trainingen. Hoe groter het callcenter, des te minder vaak nemen medewerkers klantcontact deel aan cursussen of trainingen. Dit is opvallend, omdat over het algemeen juist de grote bedrijven meer aan scholing doen dan kleine (ROA, 2000), omdat het voor grote bedrijven makkelijker is om cursussen te organiseren. Verder blijkt de cursusdeelname onder medewerkers, die bij een in-house contact center werkzaam zijn, groter dan onder medewerkers die in outsourcing contact center werken.

\subsection{Redenen om cursussen te volgen}

Welke motieven noemen medewerkers klantcontact voor het volgen van cursussen en trainingen? Uit tabel 4.2 blijkt dat 42 procent van de medewerkers klantcontact, die het afgelopen jaar een cursus gevolgd heeft, dit deed omdat de cursus verplicht was. Dit geldt met name voor de cursussen die specifiek op het werk in callcenters gericht waren. Eén callcenter springt er in dit opzicht uit: hier volgde bijna 80 procent van de medewerkers klantcontact het afgelopen jaar verplicht een cursus. Verder worden als redenen voor het volgen van een cursus het wegwerken van een tekort aan kennis en vaardigheden en bijblijven genoemd (20\%). Dit wijst erop dat medewerkers klantcontact cursussen gebruiken om hun competentietekorten aan te vullen.

Tabel 4.2

Belangrijkste motieven voor het volgen van cursussen door medewerkers klantcontact

\begin{tabular}{lc}
\hline Motief & $\%$ \\
\hline & \\
\hline Verplichte cursus & 42 \\
Verdere specialisatie & 16 \\
Wegwerken van tekort aan kennis en vaardigheden & 11 \\
Bijblijven & 9 \\
Ander werk kunnen doen & 9 \\
Vergroten kans op werk & 5 \\
Promotie kunnen maken & 5 \\
Overig (o.a. persoonlijke interesse) & 2 \\
& \\
\hline
\end{tabular}

Hebben medewerkers klantcontact, die het afgelopen jaar een cursus gevolgd hebben, nu ook daadwerkelijk minder grote skill gaps dan medewerkers die niet aan een cursus hebben deelgenomen? Tabel 4.3 wijst uit dat dit het geval is. Met name de cursussen op de terreinen 'onderhandelingstechnieken', 'bedrijfskennis', 'werkprocedures' en 'telefonische verkooptechniek' blijken in dit opzicht veel nut te hebben. Van de medewerkers klantcontact die het afgelopen jaar één van deze cursussen gevolgd heeft, heeft een veel geringer deel nog last van deze skill gaps dan bij de medewerkers die geen cursus gevolgd hebben. 
Tabel 4.3

Percentage medewerkers klantcontact met een skill gap na het al dan niet volgen van een cursus

$\begin{array}{ccc}\text { Cursus } & \begin{array}{c}\text { Cursus wel gevolgd } \\ \text { met skill gap }\end{array} & \begin{array}{c}\text { Cursus niet gevolgd } \\ \text { met skill gap } \\ \%\end{array} \\ & & \begin{array}{c}\% \\ 0\end{array}\end{array}$

Algemeen

Probleemoplossing

Stressbeheersing

Omgaan met kwaadheid en agressie

Onderhandelingstechnieken

Motivatie

Computervaardigheden

Talenkennis

$\begin{array}{rr}4 & 5 \\ 7 & 4 \\ 8 & 7 \\ 8 & 21 \\ 5 & 8 \\ 4 & 4 \\ 16 & 24\end{array}$

Specifiek voor werk in callcenters

Klantgerichtheid

Productkennis

Bedrijfskennis

Basisgesprekstechnieken

Werkprocedures

Telefonische verkooptechniek

$\begin{array}{rr}1 & 3 \\ 9 & 14 \\ 11 & 19 \\ 1 & 2 \\ 4 & 12 \\ 21 & 39\end{array}$

Naast het deelnemen aan cursussen en trainingen kunnen medewerkers klantcontact hun competentietekorten ook aanvullen door te leren op de werkplek. In het vorige hoofdstuk hebben we al gezien dat medewerkers met veel werkervaring minder grote skill gaps hebben op 'telefonische verkooptechniek' en 'productkennis'. Door met collega's te praten en te werken, vergaren werknemers kennis en verbeteren ze hun vaardigheden. Ook het uitvoeren van het werk maakt dat men er steeds beter in wordt (al doende leert men).

Tabel 4.4

Belang van het volgen van een cursus en belang van werkervaring voor het verminderen van skill gaps (- niet belangrijk; + enigszins belangrijk; ++ zeer belangrijk).

\begin{tabular}{lcc}
\hline Skill gap & Cursus gevolgd & Werkervaring \\
\hline Algemeen & & \\
Probleemoplossing & - & ++ \\
Stressbeheersing & - & - \\
Omgaan met kwaadheid en agressie & - & - \\
Onderhandelingstechnieken & + & - \\
Motivatie & - & + \\
Computervaardigheden & - & - \\
Talenkennis & - & - \\
Specifiek voor werk in callcenters & & ++ \\
Klantgerichtheid & - & - \\
Productkennis & ++ & - \\
Bedrijfskennis & ++ & - \\
Basisgesprekstechnieken & - & + \\
Werkprocedures & - & \\
Telefonische verkooptechniek & ++ & \\
& & \\
\hline
\end{tabular}

In tabel 4.4 is de invloed van zowel het volgen van cursussen als het leren op de werkplek op de skill gaps van medewerkers klantcontact aangegeven. Nadat er 
rekening gehouden is met andere kenmerken van medewerkers en bedrijven ${ }^{8}$ blijkt dat medewerkers klantcontact met veel werkervaring minder grote skill gaps hebben in de competenties 'probleemoplossing', 'productkennis', 'computervaardigheden' en 'telefonische verkooptechniek'. Blijkbaar speelt het leren op de werkplek een grote rol bij het verwerven van deze competenties. Skill gaps in 'telefonische verkooptechniek' blijken overigens nog beter opgelost te kunnen worden door het volgen van een cursus op dit terrein. Deelname aan cursussen verkleint ook de competentietekorten in de product- en bedrijfskennis van medewerkers klantcontact en in hun onderhandelingstechnieken.

\subsection{Tevredenheid met cursussen}

Medewerkers klantcontact die in het afgelopen jaar een cursus gevolgd hebben zijn tevreden over de scholingsfaciliteiten die hen geboden worden. Figuur $4.1 \mathrm{geeft}$ aan dat maar liefst driekwart van de medewerkers (zeer) tevreden is met de scholingsfaciliteiten bij het callcenter. Ook over de begeleiding op de werkplek is men in het algemeen (zeer) tevreden. De verschillen tussen de acht onderzochte callcenters zijn niet zo groot, al is er één callcenter waar ruim de helft van medewerkers klantcontact ontevreden is over de scholingsfaciliteiten en de begeleiding op de werkplek. Opmerkelijk is dat dit callcenter veel cursussen aan haar medewerkers aanbiedt en dat ook veel medewerkers het afgelopen jaar een cursus gevolgd hebben.

Figuur 4.1

Tevredenheid van medewerkers klantcontact over de scholingsfaciliteiten en de begeleiding op de werkplek

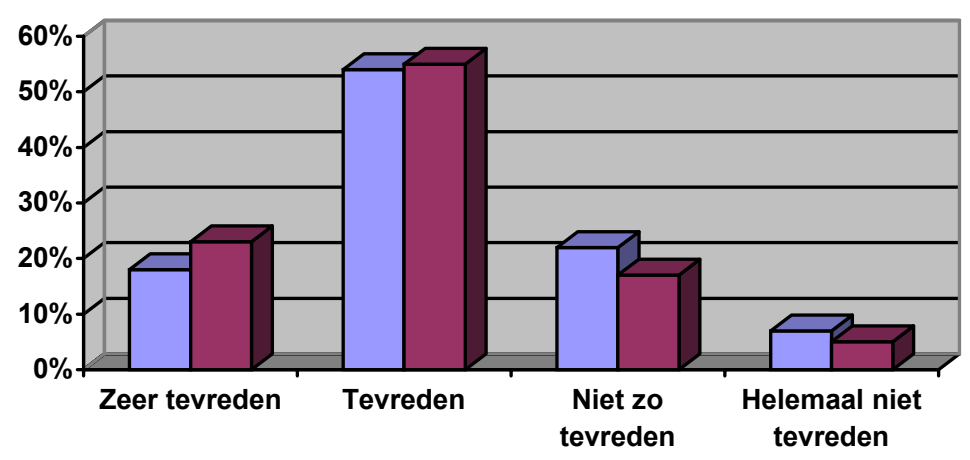

口Scholingsfaciliteiten $\square$ Begeleiding op de werkplek

\subsection{Wens naar toekomstige cursussen}

De wens onder medewerkers klantcontact om in de nabije toekomst aan cursussen en trainingen deel te nemen is groot. Maar liefst 61 procent van de medewerkers

8. Deze kenmerken zijn geslacht, leeftijd, opleidingsniveau en -richting, het al dan niet in deeltijd werken, het soort gesprekken dat men voert, de grootte van het callcenter en of het een in-house of outsourcing contact center betreft. 
klantcontact denkt in de komende 12 maanden een cursus te gaan volgen. Deze cursussen liggen dan voornamelijk op het terrein van de product- en bedrijfskennis en computervaardigheden (zie tabel 4.5). In het algemeen geven medewerkers klantcontact met een skill gap vaker aan in de toekomst een cursus of training op dat gebied te willen volgen dan medewerkers klantcontact zonder een skill gap. Met name bij de wens om deel te nemen aan cursussen in probleemoplossing, computervaardigheden en basisgesprekstechnieken zijn er duidelijke verschillen te zien tussen medewerkers met en zonder competentietekorten op deze terreinen. Dit geeft aan dat medewerkers klantcontact met een skill gap aanvoelen dat ze hun competentietekorten moeten wegwerken om goed te kunnen functioneren en ook dat zij bereid zijn hiervoor een cursus te volgen.

Tabel 4.5

Wens naar toekomstige cursussen

\begin{tabular}{lccr}
\hline Cursus & $\begin{array}{c}\text { Met skill gap } \\
\%\end{array}$ & $\begin{array}{c}\text { Zonder skill gap } \\
\%\end{array}$ & $\begin{array}{c}\text { Totaal } \\
\%\end{array}$ \\
& & & \\
Algemeen & & 11 & 13 \\
Probleemoplossing & 46 & 3 & 3 \\
Stressbeheersing & 8 & 6 & 6 \\
Omgaan met kwaadheid en agressie & 9 & 2 & 5 \\
Onderhandelingstechnieken & 8 & 5 & 34 \\
Motivatie & 5 & 10 & 9 \\
Computervaardigheden & 64 & & 11 \\
Talenkennis & 5 & 11 & 43 \\
Specifiek voor werk in callcenters & & 44 & 26 \\
Klantgerichtheid & 0 & 27 & 18 \\
Productkennis & 39 & 7 & 10 \\
Bedrijfskennis & 22 & 18 & 7 \\
Basisgesprekstechnieken & 40 & 7 & \\
Werkprocedures & 20 & & \\
Telefonische verkooptechniek & 11 & & \\
& & & \\
\end{tabular}




\section{Competenties, werkervaring en arbeidsmarktpositie}

\subsection{Inleiding}

De kennis en vaardigheden, die medewerkers klantcontact bezitten, zijn niet alleen van belang voor het goed kunnen vervullen van hun functie. Competenties, of het tekort hieraan, bepalen naast iemands productiviteit ook diens arbeidsmarktpositie, zowel binnen als buiten de callcenter sector. lemand met veel competenties is gewilder op de arbeidsmarkt. Medewerkers, die gemotiveerd en stressbestendig zijn en die goed problemen kunnen oplossen, zijn beter in staat te reageren en te anticiperen op veranderingen in zowel arbeidstaken als werkomgeving. lemand die daarentegen over veel specifieke competenties beschikt is vooral voor het bedrijf zelf aantrekkelijk, of voor een soortgelijk werk bij een ander callcenter. lemands werkervaring kan ook een belangrijke rol in de arbeidsmarktperspectieven van medewerkers klantcontact binnen en buiten de callcentersector spelen.

In dit hoofdstuk staat de relatie tussen competenties en de arbeidsmarktpositie van medewerkers klantcontact centraal. Daarnaast komt de relatie tussen werkervaring en de arbeidsmarktpositie binnen en buiten de callcentersector aan bod. Eerst zullen in paragraaf 5.2 de loopbaanperspectieven van de medewerkers klantcontact beschreven worden. Overwegen medewerkers een baan elders te aanvaarden en in hoeverre hangt dit samen met hun competenties en werkervaring?

Vervolgens wordt in paragraaf 5.3 onderzocht om welke redenen medewerkers klantcontact overwegen om een baan elders te aanvaarden. In het verlengde hiervan wordt daarna de tevredenheid van medewerkers klantcontact met hun werk beschreven. Hoe tevreden zijn zij over de loopbaanperspectieven, het salaris, de werktijden, de inhoud van het werk en de werksfeer? Ook wordt gekeken of de ontevredenheid van medewerkers ertoe leidt dat zij overwegen om een baan elders te aanvaarden.

Ten slotte wordt in paragraaf 5.4 ingegaan op de arbeidsmarktperspectieven van de medewerkers klantcontact. Dit geeft een belangrijke indicatie van de concurrentiepositie die de callcenters op de arbeidsmarkt innemen. Hoe percipiëren medewerkers hun mogelijkheden om binnen en buiten de callcenter sector werk te vinden? En in hoeverre hangt dit af van de competenties en de werkervaring die medewerkers bezitten?

\subsection{Loopbaanperspectieven}

Aan de medewerkers klantcontact van de acht onderzochte callcenters is gevraagd of ze overwegen binnen 2 jaar een baan elders te aanvaarden. Figuur 5.1 laat zien dat slechts 6 procent van de medewerkers een baan bij een ander callcenter overweegt. Het betreft hier met name mensen met een tijdelijk contract. Een veel grotere groep (35\%) overweegt een andere baan buiten de callcentersector. Met name mannen, jongeren en medewerkers met een tijdelijk contract overwegen een baan buiten de callcentersector. Dit betekent dat een aanzienlijk deel van de 
medewerkers klantcontact weliswaar niet denkt bij een ander callcenter een aantrekkelijke baan te kunnen vinden, maar wel uitziet naar ander soort werk. Ook kan hieruit geconcludeerd worden dart onder oudere medewerkers en vrouwen een grotere binding met het callcenter hebben dan jongeren en mannen. Kennelijk slagen callcenters er minder goed in deze laatste twee groepen te 'binden en boeien'.

Figuur 5.1

Percentage medewerkers klantcontact dat overweegt binnen 2 jaar een baan elders te aanvaarden

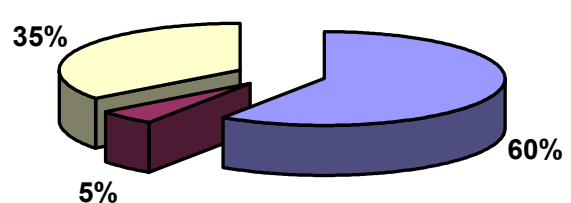

$\square$ Overweegt geen andere baan

口Overweegt baan bij ander callcenter

口Overweegt baan buiten callcentersector

Er bestaan overigens aanzienlijke verschillen tussen de acht onderzochte callcenters in het percentage medewerkers klantcontact dat overweegt een andere baan te aanvaarden. Bij twee callcenters geeft zelfs het overgrote deel van de medewerkers (respectievelijk $78 \%$ en $92 \%$ ) aan binnen 2 jaar geen andere baan te overwegen. Het gaat dan om callcenters die veel medewerkers met een vast contract in dienst hebben. Eén callcenter valt duidelijk minder in de smaak bij het personeel. Hier denkt maar liefst 91 procent van de medewerkers klantcontact binnen 2 jaar een baan elders te aanvaarden. Het werken in een callcenter bevalt hen zelfs zo slecht dat ruim driekwart van de medewerkers een baan buiten de callcentersector overweegt. Het is overigens opmerkelijk dat bij dit callcenter niet buitensporig veel medewerkers met een tijdelijk contract werkzaam zijn. Wel zijn hier relatief veel hoogopgeleiden in dienst. Dit zou er op kunnen duiden dat deze vinden dat het werk dat ze doen onder hun niveau ligt.

\section{Competenties}

In hoeverre hangt het overwegen van een andere baan samen met de competenties die medewerkers klantcontact hebben? Deze vraag is van groot belang voor callcenters. Het zou immers een slechte zaak zijn wanneer juist de medewerkers die over veel competenties beschikken vertrekken en de medewerkers met weinig competenties overblijven. Tabel 5.1 laat echter zien dat dit niet het geval is. Zo geven de eerste twee kolommen van deze tabel aan dat competente medewerkers niet vaker bij een ander callcenter willen gaan werken. Medewerkers klantcontact met een slechte of matige score op de 13 onderzochte competenties lijken zelfs iets vaker bij een andere callcenter te willen gaan werken dan medewerkers met een betere score op deze competenties ${ }^{9}$. Ook wat het overwegen van een baan buiten de callcentersector betreft, verschillen de percentages medewerkers klantcontact met een goede of een slechte score op de 13 competenties van elkaar (zie de laatste

9. Deze verschillen zijn statistisch gezien niet significant, hetgeen met name veroorzaakt wordt door de relatief kleine aantallen waarop sommige cellen van de tabel gebaseerd zijn. 
twee kolommen van tabel 5.1). Met name medewerkers die slecht scoren op de competenties 'motivatie', 'omgaan met kwaadheid en agressie', 'klantgerichtheid' en 'talenkennis' overwegen vaker een andere baan buiten het callcenter dan medewerkers die wel over deze competenties beschikken. Medewerkers, die goede 'computervaardigheden' en 'talenkennis' hebben, overwegen daarentegen vaker een andere baan buiten de callcentersector dan medewerkers die wel over deze competenties beschikken. Dit wijst erop dat callcenters er minder goed in slagen mensen die deze competenties hebben aan de sector te binden.

Tabel 5.1

Percentage medewerkers klantcontact met goede en slechte scores op competenties dat overweegt binnen 2 jaar een baan elders te aanvaarden

\begin{tabular}{|c|c|c|c|c|}
\hline \multirow[b]{2}{*}{ Competentie } & \multicolumn{2}{|c|}{$\begin{array}{l}\text { Overweegt baan bij ander } \\
\text { callcenter }\end{array}$} & \multicolumn{2}{|c|}{$\begin{array}{l}\text { Overweegt andere baan } \\
\text { buiten callcentersector }\end{array}$} \\
\hline & $\begin{array}{c}\text { Goede score } \\
\%\end{array}$ & $\begin{array}{c}\text { Slechte score } \\
\%\end{array}$ & $\begin{array}{c}\text { Goede score } \\
\%\end{array}$ & $\begin{array}{c}\text { Slechte score } \\
\%\end{array}$ \\
\hline \multicolumn{5}{|l|}{ Algemeen } \\
\hline Probleemoplossing & 5 & 12 & 35 & 32 \\
\hline Stressbeheersing & 5 & 18 & 34 & 46 \\
\hline Omgaan met kwaadheid en agressie & 5 & 6 & 34 & 53 \\
\hline Onderhandelingstechnieken & 5 & 5 & 36 & 30 \\
\hline Motivatie & 5 & 13 & 32 & 75 \\
\hline Computervaardigheden & 5 & 9 & 36 & 17 \\
\hline Talenkennis & 5 & 7 & 38 & 25 \\
\hline \multicolumn{5}{|l|}{ Specifiek voor werk in callcenters } \\
\hline Klantgerichtheid & 5 & 14 & 34 & 64 \\
\hline Productkennis & 5 & 9 & 34 & 40 \\
\hline Bedrijfskennis & 5 & 8 & 35 & 34 \\
\hline Basisgesprekstechnieken & 6 & - & 36 & 13 \\
\hline Werkprocedures & 5 & 13 & 35 & 40 \\
\hline Telefonische verkooptechniek & 5 & 6 & 31 & 39 \\
\hline
\end{tabular}

Over het algemeen spreekt uit tabel 5.1 echter het beeld dat juist de medewerkers klantcontact met weinig competenties vaker een andere baan - met name buiten de sector - overwegen dan medewerkers met veel competenties. Dit betekent dat callcenters met een gerust hart kunnen investeren in cursussen en trainingen van medewerkers. Immers, medewerkers klantcontact vertrekken niet naar een ander callcenter wanneer zij hun competenties aangevuld hebben. Bovendien overwegen deze competente medewerkers minder vaak een baan buiten de callcentersector. Het is dus zowel voor ieder callcenter afzonderlijk als voor alle callcenters samen van belang te investeren in cursussen en trainingen om zo medewerkers aan het bedrijf en de sector te binden.

\section{Werkervaring}

Werknemers met veel werkervaring zijn doorgaans gewild op de arbeidsmarkt, waadoor het voor hen makkelijk is om van baan te wisselen. Dit geldt echter vooral binnen de sector. Buiten de sector zal het wellicht moeilijker zijn om een baan te vinden wanneer men over veel specifieke werkervaring beschikt. Men spreekt in dit verband ook wel van 'ervaringsconcentratie' (Thijssen, 1996; De Grip, 2000). Dit 
beeld wordt bevestigd door de cijfers in tabel 5.2. Medewerkers klantcontact met veel werkervaring (meer dan 3 jaar) overwegen beduidend minder vaak een baan buiten de callcentersector te aanvaarden dan medewerkers met minder werkervaring. Maar liefst 70 procent van de medewerkers met veel werkervaring denkt over 2 jaar nog bij hetzelfde callcenter te werken. Het percentage dat een baan overweegt bij een ander callcenter is het grootst bij medewerkers die 1 tot 3 jaar werkervaring hebben, maar de verschillen met medewerkers die weinig (minder dan 1 jaar) of veel werkervaring hebben zijn zeer klein.

Tabel 5.2

Percentage medewerkers klantcontact met weinig, gemiddeld of veel werkervaring dat overweegt binnen 2 jaar een baan elders te aanvaarden

\begin{tabular}{lccc}
\hline Werkervaring & $\begin{array}{c}\text { Overweegt geen } \\
\text { andere baan } \\
\%\end{array}$ & $\begin{array}{c}\text { Overweegt baan bij } \\
\text { ander callcenter } \\
\%\end{array}$ & $\begin{array}{c}\text { Overweegt andere baan } \\
\text { buiten callcentersector } \\
\%\end{array}$ \\
\hline Weinig (minder dan 1 jaar) & 56 & 5 & 39 \\
Gemiddeld (1 tot 3 jaar) & 55 & 8 & 37 \\
Veel (meer dan 3 jaar) & 70 & 3 & 27 \\
\hline
\end{tabular}

\subsection{Redenen om elders te gaan werken}

Welke redenen hebben medewerkers klantcontact om binnen 2 jaar een baan elders te willen aanvaarden? Tabel 5.3 laat zien dat als belangrijkste redenen om een baan bij een ander callcenter te aanvaarden de betere loopbaanperspectieven elders $(67 \%)$ en het hogere salaris elders $(63 \%)$ genoemd worden. Deze factoren spelen ook een rol bij de overweging om een andere baan buiten de callcentersector te aanvaarden. Tevens wordt hier als reden opgegeven dat het soort werk niet bevredigend is $(47 \%)$.

Tabel 5.3

Redenen van medewerkers bij hun overweging om een baan elders te aanvaarden

\begin{tabular}{lcc}
\hline Reden & $\begin{array}{c}\text { Overweegt baan bij ander } \\
\text { callcenter } \\
\%\end{array}$ & $\begin{array}{c}\text { Overweegt andere baan } \\
\text { buiten callcentersector } \\
\%\end{array}$ \\
\hline Betere loopbaanperspectieven elders & 67 & 56 \\
Hoger salaris elders & 63 & 45 \\
Soort werk is niet bevredigend & 17 & 47 \\
Ontslag door werkgever & 20 & 3 \\
Wens om opleiding/studie te volgen & 13 & 17 \\
Werksfeer & 13 & 9 \\
Te lange reistijd & 13 & 5 \\
Opleiding of studie afgerond & 4 & 13 \\
Te hoge werkdruk & 4 & 6 \\
Onregelmatige werktijden & 4 & 5 \\
Overig (o.a. zorgtaken, verhuizing) & 20 & 24 \\
\end{tabular}




\section{Tevredenheid}

Hoe tevreden zijn medewerkers klantcontact eigenlijk met hun huidige functie? Het algemene beeld dat uit de laatste kolom van tabel 5.4 spreekt is een beeld van tevredenheid. Slechts weinig medewerkers klantcontact zijn (zeer) ontevreden over hun werk, met name over de werksfeer $(8 \%)$, werktijden $(11 \%)$, reiskostenvergoeding $(14 \%)$ en zelfstandigheid $(17 \%)$. Ten aanzien van loopbaanperspectieven en beloning is echter ongeveer eenderde ontevreden. Mannen zijn vaker dan vrouwen ontevreden over de loopbaanperspectieven en het salaris. In callcenters, waar met prestatiebeloning gewerkt wordt, zijn mannen hier ook ontevredener over dan vrouwen. Bovendien zijn ze vaker ontevreden over de zelfstandigheid, de inhoud van het werk en de werksfeer. Opmerkelijk genoeg zijn oudere medewerkers over het algemeen minder tevreden over de begeleiding op de werkplek en de scholingsfaciliteiten dan jongeren, alsook over de loopbaanperspectieven, het salaris, de prestatiebeloning en de werksfeer. De verschillen in tevredenheid tussen medewerkers klantcontact met een vast en een tijdelijk contract zijn klein, al zijn medewerkers met een tijdelijk contract wel ontevredener over de loopbaanperspectieven en de prestatiebeloning.

Tabel 5.4

Percentage medewerkers klantcontact dat (zeer) ontevreden is met verschillende werkaspecten

\begin{tabular}{lcccc}
\hline Werkaspect & $\begin{array}{c}\text { Overweegt geen } \\
\text { andere baan }\end{array}$ & $\begin{array}{c}\text { Overweegt baan } \\
\text { bij ander callcenter }\end{array}$ & $\begin{array}{c}\text { Overweegt baan } \\
\text { buiten } \\
\text { callcentersector } \\
\%\end{array}$ & Totaal \\
& $\%$ & $\%$ & & $\%$ \\
\hline Loopbaanperspectieven & 20 & 62 & 61 & 37 \\
Begeleiding op de werkplek & 16 & 32 & 31 & 22 \\
Scholingsfaciliteiten & 19 & 42 & 42 & 28 \\
Salaris & 19 & 68 & 45 & 31 \\
Prestatiebeloning & 23 & 68 & 56 & 37 \\
Reiskostenvergoeding & 9 & 30 & 47 & 14 \\
Kinderopvang & 18 & - & 13 & 11 \\
Werktijden & 11 & 4 & 39 & 22 \\
Inhoud van het werk & 12 & 25 & 28 & 17 \\
Zelfstandigheid & 11 & 15 & 33 & 25 \\
Werkdruk & 19 & 37 & 13 & 8 \\
Werksfeer & 4 & 11 & & \\
\hline
\end{tabular}

Tussen de acht onderzochte callcenters bestaan, op wat uitzonderingen na, geen grote verschillen in de ontevredenheid van medewerkers. Bij één callcenter is men wel minder tevreden over het salaris, de prestatiebeloning en de reiskostenvergoeding. In dit callcenter is modale bruto uurloon dat men aan medewerkers klantcontact ook lager dan bij de andere callcenters. Bij een ander callcenter zijn medewerkers klantcontact over bijna alle aspecten van het werk beduidend minder tevreden. Het wekt dan ook geen verbazing dat dit het callcenter is waarover we in de vorige paragraaf melden dat maar liefst $91 \%$ van de medewerkers binnen 2 jaar een andere baan denkt te aanvaarden.

Van de medewerkers klantcontact die overwegen bij een ander callcenter te gaan werken is een groot deel ontevreden over de huidige loopbaanperspectieven, het 
salaris, de prestatiebeloning en de scholingsfaciliteiten. Ook de medewerkers die buiten de callcentersector willen gaan werken zijn vaak ontevreden over deze aspecten van hun werk. Bovendien spelen hier ook nog andere aspecten een rol, zoals ontevredenheid met de kinderopvang, de inhoud van het werk, de werkdruk en begeleiding op de werkplek. Bij de medewerkers klantcontact die geen andere baan overwegen is een veel geringer deel ontevreden over hun werk.

\subsection{Arbeidsmarktperspectieven}

Om de concurrentiepositie van callcenters op de arbeidsmarkt na te gaan is aan de medewerkers klantcontact gevraagd in te schatten hoe moeilijk het voor hen is om een minstens even aantrekkelijk baan bij een ander callcenter te vinden. Ongeveer een driekwart van de medewerkers denkt dat dit niet moeilijk is (zie de linker grafiek van figuur 5.2). Over het algemeen geven mannen vaker aan moeilijkheden te zien bij het vinden van een baan bij een ander callcenter dan vrouwen. Ook medewerkers jonger dan 25 jaar en ouder dan 40 jaar denken dat het moeilijk is om een minstens even aantrekkelijke baan bij een ander callcenter te vinden. Eén callcenter, waar veel ouderen en lager opgeleiden werken, springt er in dit opzicht dan ook uit. Hier schat de helft van de medewerkers klantcontact in dat het (zeer) moeilijk is om een baan bij een ander callcenter te vinden.

Figuur 5.2

Gepercipieerde moeilijkheid om een baan bij een ander callcenter of buiten de sector te vinden door medewerkers klantcontact

Baan bij ander callcenter

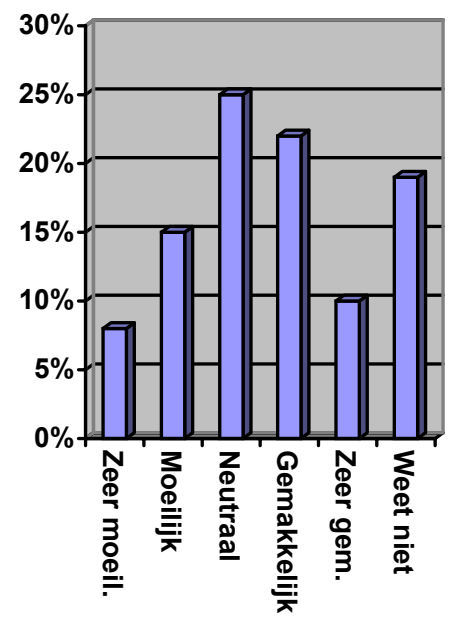

Baan buiten de sector

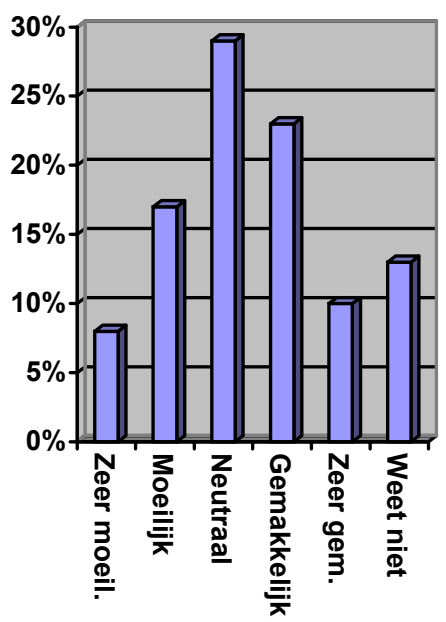

De rechter grafiek van figuur 5.2 laat zien hoe moeilijk medewerkers klantcontact het vinden om een minstens even aantrekkelijke baan buiten de callcentersector te vinden. Ook hier blijkt dat driekwart van de medewerkers denkt dat het niet moeilijk is om een dergelijke baan te vinden. Met name ouderen geven aan hier moeilijkheden te zien. Dit verklaart waarom het percentage medewerkers dat het vinden van een 
baan buiten de sector als (zeer) moeilijk inschat zo hoog is bij twee callcenters, waar veel ouderen werkzaam zijn. Een ander callcenter heeft juist veel medewerkers klantcontact in dienst die denken dat het niet zo is om elders een baan te vinden. De gemiddelde leeftijd in dit callcenter is ook beduidend lager: 26 jaar.

\section{Competenties}

Verwacht zou mogen worden dat medewerkers klantcontact die over veel competenties beschikken het minder moeilijk vinden om een minstens even aantrekkelijke baan elders te vinden.

Tabel 5.5

Percentage medewerkers klantcontact met goede en slechte scores op competenties dat het (zeer) moeilijk vindt om een baan bij een ander callcenter of buiten de sector te vinden

\begin{tabular}{|c|c|c|c|c|}
\hline \multirow[b]{2}{*}{ Competentie } & \multicolumn{2}{|c|}{$\begin{array}{c}\text { (Zeer) moeilijk om baan } \\
\text { bij ander callcenter te } \\
\text { vinden }\end{array}$} & \multicolumn{2}{|c|}{$\begin{array}{c}\text { (Zeer) moeilijk om baan } \\
\text { buiten de sector te } \\
\text { vinden }\end{array}$} \\
\hline & $\begin{array}{c}\text { Goede score } \\
\%\end{array}$ & $\begin{array}{l}\text { Slechte } \\
\text { score } \\
\%\end{array}$ & $\begin{array}{l}\text { Goede } \\
\text { score } \\
\%\end{array}$ & $\begin{array}{l}\text { Slechte } \\
\text { score } \\
\%\end{array}$ \\
\hline \multicolumn{5}{|l|}{ Algemeen } \\
\hline Probleemoplossing & 28 & 41 & 27 & 33 \\
\hline Stressbeheersing & 29 & 39 & 27 & 50 \\
\hline Omgaan met kwaadheid en agressie & 28 & 39 & 27 & 35 \\
\hline Onderhandelingstechnieken & 27 & 38 & 27 & 34 \\
\hline Motivatie & 30 & 16 & 28 & 23 \\
\hline Computervaardigheden & 29 & 42 & 27 & 35 \\
\hline Talenkennis & 27 & 36 & 24 & 43 \\
\hline \multicolumn{5}{|l|}{ Specifiek voor werk in callcenters } \\
\hline Klantgerichtheid & 29 & 33 & 28 & 23 \\
\hline Productkennis & 29 & 32 & 28 & 31 \\
\hline Bedrijfskennis & 28 & 34 & 28 & 27 \\
\hline Basisgesprekstechnieken & 30 & & 28 & \\
\hline Werkprocedures & 29 & 28 & 27 & 34 \\
\hline Telefonische verkooptechniek & 29 & 31 & 29 & 27 \\
\hline
\end{tabular}

Tabel 5.5 geeft aan dat dit beeld enigszins klopt. Het percentage medewerkers dat het (zeer) moeilijk vindt om een baan bij een ander callcenter te vinden is immers kleiner bij mensen met een goede score op de 13 competenties dan bij mensen met een slechte score. Echter, de verschillen tussen de beide groepen zijn statistisch gezien niet erg groot. Hetzelfde geldt voor de inschatting van de moeilijkheid om een baan buiten de callcentersector te vinden. lemands competenties lijken dus slechts in geringe mate een rol te spelen om een baan elders - zowel binnen als buiten de callcentersector - te vinden, althans in de perceptie van medewerkers klantcontact. Overigens hoeft dit niet te betekenen dat de marktwaarde van de meer competente medewerkers klantcontact niet hoger is dan die van de minder competente medewerkers. Deze marktwaarde zal immers al voor een belangrijk deel verdisconteerd zijn in het huidige arbeidscontract. 


\section{Werkervaring}

Interessant is ook de vraag of het voor medewerkers klantcontact met veel werkervaring moeilijker of juist gemakkelijker is om elders een baan te vinden. Zoals we in paragraaf 3.4 concludeerden, hebben medewerkers met veel werkervaring minder grote skill gaps wat hun telefonische verkooptechniek en productkennis betreft. Hierdoor zijn ze gewild op de interne arbeidsmarkt. Hun goede telefonische verkooptechniek maakt het voor hen waarschijnlijk ook minder moeilijk om een baan bij een ander callcenter te vinden. Buiten de sector zal het beschikken over veel specifieke werkervaring wellicht juist in het nadeel van de medewerkers kunnen werken. Figuur 5.3 laat zien dat deze redenering redelijk opgaat. Van de medewerkers klantcontact die minder dan 1 jaar werkervaring hebben, meent 35 procent dat het voor hen (zeer) moeilijk is om een baan bij een callcenter te vinden. Van de medewerkers met meer dan 3 jaar ervaring is slechts 24 procent die mening toegedaan. Omgekeerd geldt dat medewerkers met veel werkervaring het vaker moeilijk vinden om een baan buiten de callcentersector te vinden (41\%) dan medewerkers met weinig werkervaring (20\%).

\section{Figuur 5.3}

Percentage medewerkers klantcontact met weinig, gemiddeld of veel werkervaring dat het (zeer) moeilijk vindt om een baan bij een ander callcenter of buiten de sector te vinden

Baan bij ander callcenter

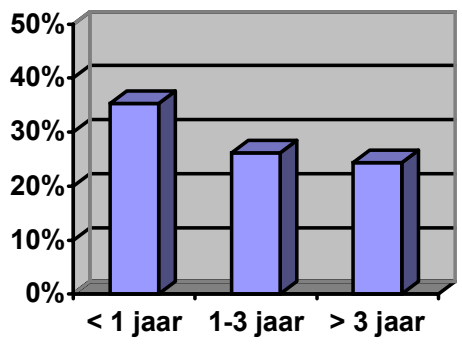

Baan buiten de sector

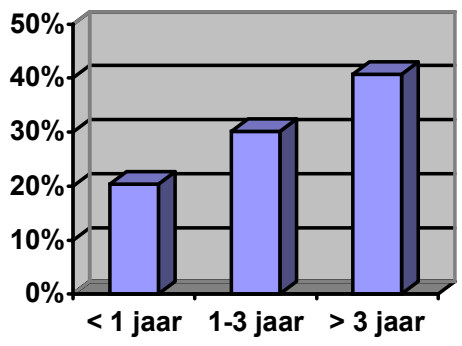

Deze bevindingen hebben een aantal belangrijke implicaties voor het Human Resource Management (HRM) beleid van callcenters. Het blijkt dat competente medewerkers minder snel omzien naar een andere baan binnen of buiten de callcentersector. Het aanbieden van cursussen en trainingen aan medewerkers klantcontact is daardoor een belangrijk middel om werknemers te binden en te boeien. Daarnaast snijdt het investeren in cursussen en trainingen ook voor medewerkers klantcontact hout. Zij kunnen door het volgen van cursussen en trainingen hiaten in hun kennis en vaardigheden aanvullen. Het blijkt dat bestaande skill gaps bij medewerkers klantcontact hierdoor verdwijnen, waardoor zij hun functie beter kunnen uitoefenen. We denken dat het investeren in cursussen en trainingen de callcenters meer perspectief biedt dan het opzetten van een specifieke opleiding voor medewerkers klantcontact in het reguliere onderwijs. Uit hoofdstuk 3 bleek immers dat de opleidingsachtergrond van medewerkers klantcontact zeer divers is. 
Juist deze opleidingsbreedte biedt callcenters een grotere actieradius op de arbeidsmarkt.

Overigens geldt hetzelfde ook voor het arbeidsaanbod. Uit het rapport van de Stuurgroep Evaluatie Wet Educatie Beroepsonderwijs (2001) komt naar voren dat er teveel sectorspecifieke MBO-opleidingen bestaan. Een aparte afstudeerrichting 'klantcontact' heeft vanuit het perspectief van de leerlingen het nadeel dat men zich veel sterker specialiseert dan wanneer men een breder georiënteerde afstudeerrichting binnen de sector economie gaat volgen. In het laatste geval heeft men ook veel meer uitwijkmogelijkheden op de arbeidsmarkt, waardoor men minder kwetsbaar is voor plotselinge verschuivingen in de werkgelegenheid binnen een bepaalde sector. Er mag dan ook worden aangenomen dat veel leerlingen niet voor een aparte afstudeerrichting 'klantcontact' zullen kiezen, maar een bredere economischcommerciële MBO-opleiding zullen prefereren.

Wel zou het goed zijn om binnen deze algemene opleidingen meer aandacht te besteden aan de kennis en vaardigheden die in callcenters gewenst zijn. In dat geval kunnen leerlingen vanuit een breder beroepsperspectief zich toch wat meer richten op het werk in callcenters. De keuze van ROC's in de regio Arnhem/Nijmegen om aparte modules klantcontact binnen bestaande MBO-opleidingen aan te bieden lijkt daarmee een slimme zet. 



\section{Literatuur}

Braaksma, R.M. (1998). Bedrijfsleven in beeld: Callcenters. EIM, Zoetermeer.

CBS (2001). Aantallen leerlingen in het voortgezet onderwijs. Centraal Bureau voor de Statistiek, Voorburg/Heerlen.

Eimers, T. \& E. Thomas (2000). Onderwijs callcenterpersoneel vraagt nieuwe aanpak. Beroepenstructuur en kwalificeringsvraag in callcenters. ITS, Nijmegen.

Grip, A. de (2000). Van tweedekansonderwijs naar een leven lang leren. De veranderende betekenis van post-initiële scholing. Universiteit Maastricht, Maastricht.

NCCBP (2001). Nationaal Contact Center Benchmark Onderzoek 2001. NCCBP/MarketResponse, Amersfoort.

Pickartz, I. von \& J. van Stigt (2001). De wereld is klant, de klant is de wereld. Tijdschrift voor Arbeidsverhoudingen/Zeggenschap, 1: 26-28.

ROA (2000). Werkgelegenheid en scholing 1999. ROA-R-2000/5, Maastricht

Stuurgroep Evaluatie WEB (2001). DE WEB: naar eenvoud en evenwicht. Eindrapport van de Stuurgroep Evaluatie WEB. Ministerie OCenW, Zoetermeer.

Thijssen, J.G.L. (1996). Leren, leeftijd en loopbaanperspectief. Kluwer Bedrijfswetenschappen, Deventer. 



\section{Bijlage: Vragenlijsten}

\section{Vragenlijst voor medewerkers klantcontact}

\section{Blok 1 Algemene informatie}

$1 \quad$ Wat is uw geslacht?

$\square$ Man

$\square$ Vrouw

$2 \quad$ Wat is uw leeftijd?

_ jaar

$3 \quad$ Heeft u een partner waarmee u een gezamenlijke huishouding voert?

$\square \mathrm{Ja}$

$\square$ Nee $\rightarrow$ ga verder met vraag 5

$4 \quad$ Wat is de persoonlijke situatie van uw partner?

(Kies het antwoord dat het meest van toepassing is)

$\checkmark$ Werkzaam in een voltijdbaan

$\square$ Werkzaam in een deeltijdbaan (32 uur of minder)

$\checkmark$ Huishoudelijk werk / zorgtaken

$\square$ Werkzoekende

$\square$ Studerend

$\square$ Arbeidsongeschikt

૫VUT / pensioen

$\square$ Anders, namelijk (s.v.p. invullen):

$5 \quad$ Heeft $u$ thuiswonende kinderen?

$\square \mathrm{Ja}$, ik heb (s.v.p. invullen) __ kinderen

$\square$ Nee $\rightarrow$ ga verder met blok 2

$6 \quad$ Hoe oud is uw jongste thuiswonende kind? jaar

Blok 2 Uw huidige functie

$7 \quad$ Wat voor soort gesprekken voert u doorgaans?

$\square$ Klant belt (inbound)

$\square$ Klant wordt gebeld (outbound)

$\square$ Beide 
8 Sinds wanneer werkt u bij dit call center? (Vul maand en jaar van indiensttreding in)

maand: jaar:

9 Hoelang heeft $\mathrm{u}$ in totaal gewerkt als medewerker klantcontact? (Tel ook de tijd bij andere contact centers mee) jaar en maanden

Wat voor type contract heeft u?

$\square$ Vast contract

$\checkmark$ Tijdelijk contract met uitzicht op vaste aanstelling

$\square$ Tijdelijk contract

$\square$ Oproepbasis $\rightarrow$ ga verder met vraag 12

11 Voor hoeveel uur per week bent u volgens uw contract in dienst? uur per week

Hoeveel uur werkt u feitelijk gemiddeld per week? uur per week

En hoeveel uur per week zou u het liefst willen werken? uur per week

Wat is uw gemiddelde bruto maandloon? (Dit is het loon vóór aftrek van belastingen en sociale premies)

$\square$ minder dan fl. 500,- per maand

$\square$ tussen fl. 500,- en fl. 1000,- per maand

$\square$ tussen fl. 1000,- en fl. 1500,- per maand

$\square$ tussen fl. 1500,- en fl. 2000,- per maand

$\square$ tussen fl. 2000,- en fl. 2500,- per maand

$\square$ tussen fl. 2500,- en fl. 3000,- per maand

$\square$ tussen fl. 3000,- en fl. 3500,- per maand

$\square$ tussen fl. 3500,- en fl. 4000,- per maand

$\square$ tussen fl. 4000,- en fl. 4500,- per maand

$\square$ tussen fl. 4500,- en fl. 5000,- per maand

$\square$ meer dan fl. 5000,- per maand

15 Hoeveel gesprekken handelt u gemiddeld per uur af? gesprekken

16 De volgende vraag gaat over uw werktijden. Kunt u aangeven hoeveel uur u gemiddeld per week 's ochtends, 's middags, 's avonds en 's nachts werkt?

- Ochtend: $\quad 08.00-13.00$

- Middag: $\quad 13.00-17.00$ 
- Avond: $\quad 17.00-21.00$

- Nacht: $\quad 21.00-08.00$

- Totaal

$17 \quad$ Werkt $u$ in de volgende diensten?

Ja Nee

- Weekenddienst

- Feestdagen

- Reserve-dienst

- Stand-by dienst (pieper)

18 Hoeveel tijd kost het u gewoonlijk om van huis op het werk te komen? (Vul de gemiddelde enkele reistijd van deur tot deur in minuten in) minuten

19 Wat is naast uw werk bij dit call center uw belangrijkste bezigheid?

$\square$ Vrije tijd

$\square$ School of studie

$\checkmark$ Zorg voor kinderen, huishoudelijk werk of andere zorgtaken

$\square$ Een andere baan, namelijk (s.v.p. invullen):

$\square$ Anders, namelijk (s.v.p. invullen):

Blok 3 Opleidingen en vaardigheden

20 Wat is uw hoogste, met een diploma afgeronde, opleiding?

$\square$ Basisschool of lagere school

$\square$ LBO

○ MAVO

I HAVO

$\square$ VWO

$\square \mathrm{MBO}$

$\square \mathrm{HBO}$

$\square$ Universiteit

$21 \quad$ En wat is de richting van deze opleiding?

$\square$ Algemeen

$\square$ Landbouw

$\square$ Onderwijs

$\square$ Techniek

$\square$ Economie

$\square$ Gezondheidszorg

$\square$ Gedrag en maatschappij

$\square$ Kunst en cultuur 
$\square$ Recht en openbare orde

$\square$ Natuurwetenschappen

$\square$ Anders, namelijk (s.v.p. invullen):

In hoeverre beheerst $u$ vreemde talen? (Geef dit met een cijfer van 1 tot en met 3 aan: $1=$ slecht, $2=$ redelijk, $3=$ goed)

Lezen Schrijven Spreken

- Engels

- Frans

- Duits

- Andere taal, namelijk (s.v.p. invullen):

a)

b)

23 In hoeverre zijn onderstaande vaardigheden van belang voor het goed vervullen van uw huidige functie?

$\begin{array}{cccc}\text { Velemaal Niet van Neutraal } & \text { Van Zeervan } \\ \text { niet van belang } & \text { belang belang } \\ \text { belang } & & & \end{array}$

- Basisgesprekstechnieken

- Telefonische

verkooptechniek

- Onderhandelingstechnieken

- Werkprocedures

- Computervaardigheden

- Talenkennis

- Stressbeheersing

- Omgaan met kwaadheid en agressie

- Probleemoplossing

- Motivatie

$\begin{array}{lllll}\square & \square & \square & \square & \square \\ \square & \square & \square & \square & \square\end{array}$

- Klantgerichtheid

- Bedrijfskennis

- Productkennis

24 Heeft $u$ de afgelopen 12 maanden één of meerdere cursussen gevolgd, of volgt $u$ of dit moment een cursus?

$\square \mathrm{Ja}$

$\square$ Nee $\rightarrow$ ga verder met vraag 27

25

Op welke terreinen lagen deze cursus(sen)? (Meerdere antwoorden mogelijk)

$\square$ Basisgesprekstechnieken 
$\square$ Telefonische verkooptechniek

$\checkmark$ Onderhandelingstechnieken

$\square$ Werkprocedures

$\checkmark$ Computervaardigheden

$\square$ Talenkennis

$\square$ Stressbeheersing

○ Omgaan met kwaadheid en agressie

$\square$ Probleemoplossing

$\square$ Motivatie

$\square$ Klantgerichtheid

$\square$ Bedrijfskennis

$\square$ Productkennis

$\square$ Anders, namelijk (s.v.p. invullen):

26 Wat is de belangrijkste reden waarom u deze cursus gevolgd heeft?

$\square$ Om mijn tekort aan kennis en vaardigheden weg te werken

$\square$ Om bij te blijven

$\square$ Om mij verder te specialiseren

$\square$ De cursus was verplicht

$\square$ Om promotie te kunnen maken

$\square$ Om ander werk te kunnen doen

$\square$ Om de kans op werk te vergroten

$\square$ Anders, namelijk (s.v.p. invullen):

27 Denkt u de komende 12 maanden een cursus te gaan volgen?

$\square \mathrm{Ja}$

$\square$ Nee $\rightarrow$ ga verder met vraag 29

28 Op welke terreinen zal deze cursus liggen? (Meerdere antwoorden mogelijk)

$\checkmark$ Basisgesprekstechnieken

૫Telefonische verkooptechniek

$\square$ Onderhandelingstechnieken

$\square$ Werkprocedures

$\square$ Computervaardigheden

$\square$ Talenkennis

$\checkmark$ Stressbeheersing

○ Omgaan met kwaadheid en agressie

$\checkmark$ Probleemoplossing

$\square$ Motivatie

Klantgerichtheid

$\square$ Bedrijfskennis 
$\square$ Productkennis

$\square$ Anders, namelijk (s.v.p. invullen):

29 Kunt u met een cijfer tussen de 1 en 4 aangeven in hoeverre $u$ de volgende vaardigheden bezit? (1=slecht, 2=matig, 3=voldoende, 4=goed)

Vaardigheid

Cijfer

- Basisgesprekstechnieken

- Telefonische verkooptechniek

- Onderhandelingstechnieken

- Werkprocedures

- Computervaardigheden

- Talenkennis

- Stressbeheersing

- Omgaan met kwaadheid en agressie

- Probleemoplossing

- Motivatie

- Klantgerichtheid

- Bedrijfskennis

- Productkennis

Blok 4 Opvattingen en verwachtingen

$30 \quad$ Hoe tevreden bent u over de volgende aspecten van uw werk?

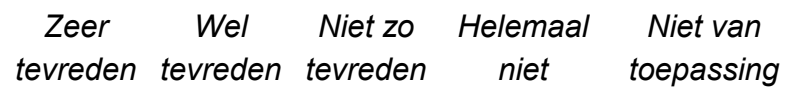

- Begeleiding op de

werkplek

- Scholingsfaciliteiten

- Zelfstandigheid

tevreden

- Inhoud van het werk

- Loopbaanperspectieven

- Salaris

- Prestatiebeloning

- Reiskostenregeling

- Werktijden

- Werksfeer

$\begin{array}{ll}\square & \square \\ \square & \square \\ \square & \square \\ \square & \square \\ \square & \square \\ \square & \square \\ \square & \square \\ \square & \square \\ \square & \square \\ \square & \square \\ \square & \square \\ \square & \square\end{array}$

- Kinderopvang

31 Overweegt u binnen 2 jaar een baan elders te aanvaarden?

$\square$ Nee $\rightarrow$ ga verder met vraag 33

$\square \mathrm{Ja}$, bij een ander call center 
$\square$ Ja, maar niet bij een call center

32 Waarom denkt u over 2 jaar niet meer bij dit call center te werken? (Meerdere antwoorden mogelijk)

$\checkmark$ Betere loopbaanperspectieven elders

$\square$ Hoger salaris elders

$\square$ Soort werk is niet bevredigend

$\square$ Te weinig werk

$\square$ Te lange reistijd

$\square$ Te hoge werkdruk

૫ Onregelmatige werktijden

$\square$ Werksfeer

$\square$ Wil een opleiding/studie gaan volgen

$\square$ Zorg voor kinderen, huishoudelijk werk of andere zorgtaken

$\square$ Gezondheidsproblemen/arbeidsongeschiktheid

$\square$ Verhuizing

$\square$ Onenigheid op de werkvloer

$\checkmark$ Ontslag door werkgever

$\square$ Anders, namelijk (s.v.p. invullen):

33 Hoe moeilijk is het volgens $u$ om op dit moment een voor u minstens even aantrekkelijke baan te vinden bij een ander call center?

$\square$ Zeer moeilijk

$\square$ Moeilijk

$\square$ Neutraal

$\square$ Gemakkelijk

$\square$ Zeer gemakkelijk

$\square$ Weet niet

34 Hoe moeilijk is het volgens $u$ om op dit moment een voor $u$ minstens even aantrekkelijke baan te vinden buiten de sector?

$\checkmark$ Zeer moeilijk

$\square$ Moeilijk

$\square$ Neutraal

$\square$ Gemakkelijk

$\square$ Zeer gemakkelijk

$\square$ Weet niet 



\section{Vragenlijst voor managers callcenters}

1 Wat is de naam van het bedrijf?

2 Wat zijn de eerste vier cijfers van de postcode van het contact center?

3 Hoeveel werknemers werken er in totaal bij dit contact center? En hoeveel medewerkers klantcontact? medewerkers totaal medewerkers klantcontact

$4 \quad$ Wat is het karakter van het contact center? $\square$ In-house contact center (binnen het bedrijf)

$\checkmark$ Outsourcing contact center (ingehuurd door andere bedrijven)

$5 \quad$ Welke taken worden in het contact center uitgevoerd?

$\square$ Inbound (klant belt)

$\square$ Outbound (klant wordt gebeld)

$\square$ Beide

6 Wat zijn de belangrijkste functies die door het contact center vervuld worden? (Meerdere antwoorden mogelijk)

$\square$ Service

$\square$ Verkoop/reserveringen/lead generation

$\square$ Helpdesk

$\square$ Klachtenafhandeling

$\square$ Marktonderzoek

૫Databaseverrijking en controle

$7 \quad$ Heeft het contact center te maken met internationale gesprekken?

$\square \mathrm{Ja}$

$\square$ Nee

8 Welk beloningssysteem wordt er voor medewerkers klantcontact gehanteerd?

$\square$ Alleen een vast honorarium

$\square$ Vast honorarium en prestatietoeslag

$\square$ Vast honorarium en toeslag op bepaalde taken

$\square$ Alleen op uur-basis

$\square$ Alleen op commissie-basis

$\checkmark$ Per gesprek 
9 Worden er toeslagen aan medewerkers klantcontact voor de volgende diensten betaald, en zo ja hoeveel?

$\begin{array}{lcccc}\text { - Avonddienst } & \square & \square & \square & -\% \\ \text { - Weekenddienst } & \square & \square & \square & -\% \\ \text { - Feestdagen } & \square & \square & \square & -\% \\ \text { - Reserve-dienst } & \square & \square & \square & -\% \\ \text { - Stand-by dienst (pieper) } & \square & \square & \square & -\end{array}$

10 Hoe hoog was het ziekteverzuim in het jaar 2000? (exclusief zwangerschapsverlof) $\%$

11 Welke trainingen biedt het contact center aan medewerkers klantcontact aan? (Meerdere antwoorden mogelijk)

$\square$ Basisgesprekstechnieken

$\square$ Telefonische verkooptechniek

$\square$ Onderhandelingstechnieken

$\square$ Werkprocedures

$\square$ Computervaardigheden

$\square$ Talenkennis

$\square$ Stressbeheersing

$\square$ Omgaan met kwaadheid en agressie

$\checkmark$ Probleemoplossing

$\square$ Motivatie

$\square$ Klantgerichtheid

$\square$ Bedrijfskennis

$\square$ Productkennis

$\square$ Anders, namelijk (s.v.p. invullen):

12 In hoeverre zijn onderstaande vaardigheden van belang voor het goed vervullen van de functie van medewerker klantcontact?

$\begin{array}{cccc} & \text { Helemaal Niet van Neutraal Van Zeervan } \\ \text { niet van belang } & \text { belang belang } \\ \text { belang } & & & \end{array}$

$\begin{array}{llllll}\text { - Basisgesprekstechnieken } & \square & \square & \square & \square & \square \\ \text { - Telefonische } & \square & \square & \square & \square & \square \\ \text { verkooptechniek } & & & & & \\ \text { - Onderhandelingstechnieken } & \square & \square & \square & \square & \square \\ \text { - Werkprocedures } & \square & \square & \square & \square & \square \\ \text { - Computervaardigheden } & \square & \square & \square & \square & \square\end{array}$


- Talenkennis

$\begin{array}{lllll}\square & \square & \square & \square & \square \\ \square & \square & \square & \square & \square \\ \square & \square & \square & \square & \square \\ \square & \square & \square & \square & \square \\ \square & \square & \square & \square \\ \square & \square & \square & \square & \square \\ \square & \square & \square & \square & \square \\ \square & \square & \square & \square & \square \\ \square & \square & \square & \square & \square\end{array}$

